\title{
A Particularly Serious Exception to the Categorical Approach
}

Fatma E. Marouf

Texas A\&M University School of Law, fatma.marouf@law.tamu.edu

Follow this and additional works at: https://scholarship.law.tamu.edu/facscholar

Part of the Civil Rights and Discrimination Commons, Human Rights Law Commons, and the Immigration Law Commons

\section{Recommended Citation}

Fatma E. Marouf, A Particularly Serious Exception to the Categorical Approach, 97 B.U. L. Rev. 1427 (2017).

Available at: https://scholarship.law.tamu.edu/facscholar/876

This Article is brought to you for free and open access by Texas A\&M Law Scholarship. It has been accepted for inclusion in Faculty Scholarship by an authorized administrator of Texas A\&M Law Scholarship. For more information, please contact aretteen@law.tamu.edu. 


\title{
A PARTICULARLY SERIOUS EXCEPTION TO THE CATEGORICAL APPROACH
}

\author{
FATMA MAROUF*
}

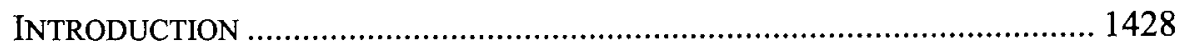

I. THE CATEGORICAL APPROACH .................................................. 1430

A. The Significance of the Word "Convicted"............................ 1432

B. Conviction for a "Particularly Serious Crime"....................... 1436

C. The BIA's Quasi-Categorical Approach ............................... 1445

1. The Unidentified Elements of a Particularly Serious

Crime

2. Ad Hoc Decisions About Whether to Use an Element-Based or

Fact-Based Approach ............................................... 1452

II. THE INDIVIDUALIZED APPROACH........................................... 1454

A. Historical Origins.............................................................. 1454

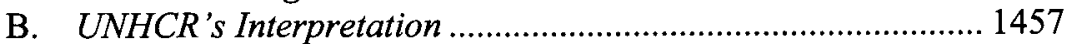

C. The BIA's Deviation from UNHCR's Approach..................... 1459

1. Failing to Consider All Mitigating Factors....................... 1459

2. Dropping Dangerousness............................................... 1461

3. Failure to Apply the Principle of Proportionality .............. 1463

III. POSSIBLE PATHS FORWARD ......................................................... 1469

A. Applying the Categorical Approach ...................................... 1469

B. Combining a Categorical and Factual Analysis .................... 1473

C. Applying an Individualized Approach ................................. 1479

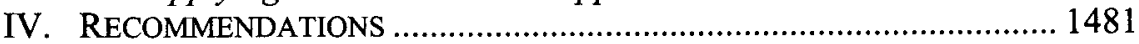

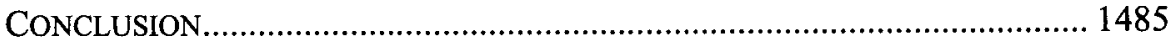

A noncitizen who has been convicted of a "particularly serious crime" can be deported to a country where there is a greater than fifty percent chance of persecution or death. Yet, the Board of Immigration Appeals has not provided a clear test for determining what is a "particularly serious crime." The current test, which combines an examination of the elements with a fact-specific inquiry, has led to arbitrary and unpredictable decisions about what types of offenses are "particularly serious." This Article argues that the categorical approach for analyzing convictions should be applied to the particularly serious crime determination to promote greater uniformity and provide the predictability

* Professor of Law, Texas A\&M University School of Law. Many thanks to Sameer Ashar, Jennifer Koh, Annie Lai, and other participants in the U.C. Irvine Clinical Scholarship Workshop who provided very helpful comments on an earlier draft of this Article. Any errors are my own. 
necessary to make informed pleas. Recent Supreme Court decisions, as well as a 2015 opinion by the Attorney General, support this argument by stressing that the use of the word "convicted" in the Immigration and Nationality Act triggers a categorical analysis. Although the United Nations High Commissioner for Refugees has interpreted the particularly serious crime bar as requiring an individualized analysis, this Article argues that the categorical approach better protects the High Commissioner's underlying concerns of consistency and fairness.

\section{INTRODUCTION}

Under the Immigration and Nationality Act ("INA"), a noncitizen facing deportation who demonstrates a greater than fifty percent chance of persecution on account of race, religion, nationality, membership in a particular social group, or political opinion may be eligible for a form of relief called "withholding of removal." The Refugee Act of 1980 incorporated withholding of removal into the INA in order to comply with the international obligation of nonrefoulement under the 1951 United Nations Convention Relating to the Status of Refugees and the 1967 Protocol Relating to the Status of Refugees (the "Refugee Convention" and the "Protocol," respectively). ${ }^{2}$ This obligation prohibits the United States from sending someone to a country where her life or freedom would be threatened. ${ }^{3}$ There are, however, certain exceptions to this prohibition. If it is determined that "the alien, having been convicted by a final judgment of a particularly serious crime is a danger to the community of the United States," then the person is barred from withholding of removal and ordered deported despite a potentially serious risk of persecution or death. ${ }^{4}$ This statutory provision mirrors the language of the Refugee Convention and is commonly known as the "particularly serious crime" bar. ${ }^{5}$

The test currently used by the Board of Immigration Appeals ("BIA") to determine whether the particularly serious crime bar applies combines an examination of the elements of a crime with an inquiry into some of the individualized facts. ${ }^{6}$ This approach is inconsistent with the categorical

18 U.S.C. $\S 1231$ (b)(3)(A) (2012); 8 C.F.R. $\S 208.16$ (b)(2) (2017) (outlining the "more likely than not" standard).

2 Refugee Act of 1980, Pub. L. No. 96-212, 94 Stat. 102 (codified in scattered sections of 8 U.S.C.); H.R. REP. No. 96-608, at 17-18 (1979); see also Protocol Relating to the Status of Refugees, Jan. 31, 1967, 19 U.S.T. 6223 [hereinafter Protocol]; Convention Relating to the Statute of Refugees, July 28, 1951, 140 U.N.T.S. 1954 [hereinafter Refugee Convention].

${ }^{3} 8$ U.S.C. $\S 1231$ (b)(3)(A); 8 C.F.R. $\S 208.16$ (b)(2).

${ }_{4} 8$ U.S.C. $\$ 1231(\mathrm{~b})(3)(\mathrm{B})$ (ii) (emphasis added).

${ }^{5}$ See Refugee Convention, supra note 2, at 176 (indicating that the right to remain in the country due to fear of prosecution is inapplicable if "there are reasonable grounds for regarding as a danger to the security of the country ... having been convicted by a final judgment of a particularly serious crime").

${ }^{6}$ See In re N-A-M-, 24 I. \& N. Dec. 336, 342 (B.I.A. 2007). 
approach for analyzing convictions, which focuses on the elements of the crime. Several recent Supreme Court decisions have addressed the categorical approach, clarifying various splits among the courts of appeals regarding how this approach should be applied and emphasizing the importance of the statutory term "convicted" in triggering a categorical analysis. ${ }^{7}$ In light of these decisions, an April 2015 opinion by Attorney General Eric Holder vacated an earlier decision by Attorney General Michael Mukasey that had permitted departures from the categorical approach for crimes involving moral turpitude ("CIMTs"); CIMTs are both a ground of deportability and a bar to certain forms of relief from removal under the INA. ${ }^{8}$ The new opinion underscores that the word "convicted" requires examining the elements of a crime rather than the underlying facts. ${ }^{9}$

This Article argues that the categorical approach should also be applied to the particularly serious crime bar, which uses the word "convicted" but, strikingly, has never been subject to this analysis. The BIA has stated in dicta that the categorical approach does not apply to the particularly serious crime determination because the latter is discretionary. ${ }^{10}$ Yet appellate courts have not consistently treated this determination as discretionary, nor have most of them explicitly addressed the question of whether the statutory language requires a categorical analysis in light of recent Supreme Court cases. ${ }^{11}$ Thus, there remains an open legal question about whether the categorical approach should be applied to the particularly serious crime bar. Furthermore, even if courts decide that a categorical analysis is not required, this Article argues that the BIA should adopt this approach in order to promote uniformity and predictability.

Part I of this Article explains the categorical approach, discussing the significance of the statutory term "convicted" under recent Supreme Court decisions and in the Matter of Silva-Trevino. Part I then discusses the BIA's current test for determining whether the particularly serious crime bar applies and how that test emphasizes the elements of an offense, yet deviates from the categorical approach. One of the main problems with the current test is that the

7 See, e.g., Descamps v. United States, 133 S. Ct. 2276, 2279 (2013); Moncrieffe v. Holder, 133 S. Ct. 1678, 1690 (2013) ("[T]he relevant INA provisions ask what the noncitizen was 'convicted of,' not what he did, and the inquiry in immigration proceedings is limited accordingly."); Kawashima v. Holder, 132 S. Ct. 1166, 1172 (2012) (analyzing whether the defendants' actions involved fraud or deceit through the categorical approach and looking at the definition of the crime in the statute rather than "the specific facts underlying the crime"); Carachuri-Rosendo v. Holder, 560 U.S. 563, 579-80 (2010) (focusing on the importance of the actual conviction as "the relevant statutory hook").

${ }^{8}$ See generally In re Silva-Trevino, 26 I. \& N. Dec. 550 (Att'y Gen. 2015) (rejecting the approach of Attorney General Mukasey which allowed judges to consider information outside of the categorical approach when there was a conviction potentially involving moral turpitude).

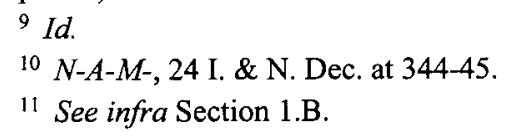


BIA has never identified specific elements that are required for a conviction to constitute a particularly serious crime. Another critical issue is that the BIA's test allows, but does not require, immigration judges to look at the underlying facts and circumstances; this leads to ad hoc decisions about whether to base the particularly serious crime determination on the elements alone or on a combination of elements and facts.

Part II of this Article examines the argument that our international obligation of nonrefoulement calls for an individualized analysis. The United Nations High Commissioner for Refugees ("UNHCR"), the U.N. agency in charge of implementing the Refugee Convention and Protocol, has interpreted the particularly serious crime bar as requiring an individualized approach that takes into consideration all mitigating and aggravating factors. This Part explains that the BIA's current approach does not comport with UNHCR's interpretation any more than it complies with the categorical approach. Specifically, the BIA has parted ways with UNHCR by refusing to apply the principle of proportionality; rejecting dangerousness as a distinct requirement; and excluding certain individualized facts from consideration, such as offender characteristics, evidence of rehabilitation, and the role of mental illness in a crime.

Part III of this Article explores three possible paths forward in interpreting the particularly serious crime bar: (1) applying the categorical approach, (2) applying a categorical analysis to the conviction combined with a fact-specific inquiry into dangerousness, and (3) applying a completely individualized analysis. This Article contends that the categorical approach, while imperfect, is the best option, as it addresses UNHCR's underlying concerns related to consistency and fairness better than a highly subjective, individualized analysis. This Article also proposes specific elements to define a "particularly serious crime," arguing that careful selection of these elements can help ensure that the conviction itself demonstrates dangerousness and that the principle of proportionality is upheld. This approach would make the categorical approach more consistent with UNHCR's interpretation than the BIA's current test. Given the gravity of being deported to a country where there is a serious risk of persecution or death, a principled, predictable approach to the particularly serious crime bar is necessary.

\section{THE CATEGORICAL APPROACH}

Courts have long applied the "categorical approach" in determining whether a given conviction triggers a ground of deportability or a bar to relief from removal under the INA. Judicial decisions dating back to 1913 employ this approach in analyzing immigration laws. ${ }^{12}$ Under the categorical approach, a court is concerned with the statute of conviction, not the facts of the underlying

12 Alina Das, The Immigration Penalties of Criminal Convictions: Resurrecting Categorical Analysis in Immigration Law, 86 N.Y.U. L. REV. 1669, 1688-702, 1749-52 (2011); see also Moncrieffe, 133 S. Ct. at 1685 ("This categorical approach has a long pedigree in our Nation's immigration law."). 
offense. The court compares the elements required for conviction under the state statute with the "generic" offense, which is the way the crime is "commonly understood;" 13 the offense "must be viewed in the abstract, to see whether the state statute shares the nature of the federal offense that serves as a point of comparison." 14 A categorical match exists only if the state statute requires all of the elements of the generic federal offense for a conviction. ${ }^{15}$ The actual conduct involved in the offense is completely irrelevant to the analysis. ${ }^{16}$

If there is no categorical match, that is usually the end of the analysis, and the ground of deportability or bar to relief is not triggered. The Supreme Court recently clarified that only when a statute is divisible-i.e., where it lists multiple alternative elements thereby including several different crimes - does the analysis continue beyond the categorical approach. ${ }^{17}$ In this situation, an immigration judge must use the "modified categorical approach" to consult a limited set of documents - the record of conviction - to identify the crime of conviction in order to compare it to the generic offense. The record of conviction includes charging documents, any plea agreement or colloquy, any jury instructions, the verdict, and the sentence. ${ }^{18} \mathrm{~A}$ court may not consider other documents such as, for example, arrest reports, witness statements, or any other evidence related to the offense. ${ }^{19}$ Upon consulting the record of conviction, "[t]he court can then do what the categorical approach demands: compare the elements of the crime of conviction (including the alternative element used in the case) with the elements of the generic crime."20 Thus, the modified approach "acts not as an exception, but instead as a tool" that "retains the categorical approach's central feature: a focus on the elements, rather than the facts, of a crime."21 Because the modified categorical approach is really just a way to implement the categorical approach, this Article uses the term "categorical approach" as shorthand for the combination of these approaches.

\footnotetext{
${ }^{13}$ Descamps v. United States, 133 S. Ct. 2276, 2281 (2013).

14 Moncrieffe, 133 S. Ct. at 1684.

${ }^{15}$ Id.

${ }^{16} \mathrm{Id}$.

${ }_{17}$ Descamps, 133 S. Ct. at 2285.

${ }^{18}$ Id. at 2296 (Alito, J., dissenting); see also Johnson v. United States, 559 U.S. 133, 144 (2010) (stating that a court can consider "charging documents, plea agreements, transcripts of plea colloquies, findings of fact and conclusions of law from a bench trial, and jury instructions and verdict forms"); Shepard v. United States, 544 U.S. 13, 20-21 (2005) (indicating that when there is a generic conviction, the court could consider charging documents filed and recorded judicial acts, such as jury instructions).

19 Johnson, 559 U.S. at 144 (limiting the factual inquiry to only "the trial record").

${ }^{20}$ Descamps, $133 \mathrm{~S}$. Ct. at 2281.

21 Id. at 2285 .
} 


\section{A. The Significance of the Word "Convicted"}

Several recent decisions by the Supreme Court addressing the categorical approach have emphasized that the use of the word "convicted" plays a critical role in triggering this mode of analysis. In Carachuri-Rosendo v. Holder, ${ }^{22}$ the Court considered whether a lawful permanent resident who had lived in the United States since he was five years old was barred from a form of relief called cancellation of removal based on an "aggravated felony" conviction under the INA. ${ }^{23}$ Jose Angel Carachuri-Rosendo had been convicted of two misdemeanor drug-possession offenses under Texas law. ${ }^{24}$ The first conviction was for possession of less than two ounces of marijuana, which resulted in a twenty-day jail sentence, and the second conviction was for possession of a single Xanax pill without a prescription, which resulted in a ten-day jail sentence. ${ }^{25}$ The issue was whether the second conviction fell under the aggravated felony ground for "illicit trafficking in a controlled substance... including a drug trafficking crime (as defined in section 924(c) of Title 18)."26 The federal statute cited defines "drug trafficking crime" to include "any felony punishable under the Controlled Substances Act." 27 The BIA and the Fifth Circuit both found that the second simple drug possession offense in this case was an aggravated felony under the INA because the conduct-recidivist simple possessionhypothetically could have been punished as a felony had it been prosecuted in federal court under the Controlled Substances Act. ${ }^{28}$

In rejecting this reasoning, the Supreme Court stressed that the statutory bar to cancellation of removal requires the lawful permanent resident to have "been convicted of $\mathrm{a}[\mathrm{n}]$ aggravated felony." 29 Based on the plain language of the statute, the Court reasoned that: "The text . . . indicates that we are to look to the conviction itself as our starting place, not to what might have or could have been charged." 30 Because the prosecutor had never actually charged CarachuriRosendo with the existence of the prior simple possession, he was not actually convicted of a drug possession committed after a prior conviction had become final. ${ }^{31}$ In finding that an immigration judge could not rely on uncharged facts, the Court stressed that the conviction is "the relevant statutory hook." 32

22560 U.S. $563(2010)$.

${ }^{23} \mathrm{Id}$. at 563 .

${ }^{24} \mathrm{Id}$.

${ }^{25}$ Id. at $570-71$.

${ }^{26} 8$ U.S.C. $\S 1101(\mathrm{a})(43)(\mathrm{B})(2012)$.

${ }^{27} 18$ U.S.C. $\$ 924(c)(2)(2012)$.

28 Carachuri-Rosendo, 560 U.S. at 572-73.

${ }^{29} I d$. at 576 (quoting 8 U.S.C. $\S 1229 \mathrm{~b}(\mathrm{a})(3)$ ).

${ }^{30} \mathrm{Id}$.

31 Id. at 582.

${ }^{32} \mathrm{Id}$. at 580. 
The Supreme Court's 2013 decision in Moncrieffe v. Holder ${ }^{33}$ applied the reasoning of Carachuri-Rosendo in considering whether a conviction for possession of marijuana with intent to distribute under a Georgia statute constituted an aggravated felony under the INA. ${ }^{34}$ Adrian Moncrieffe was caught with 1.3 grams of marijuana in his car-the equivalent of two or three marijuana cigarettes - during a traffic stop. ${ }^{35}$ The Court held that if a conviction for marijuana distribution fails to establish that the offense involved either remuneration or more than a small amount of marijuana, it is not an aggravated felony under the INA. ${ }^{36}$ Once again, the Court stressed that "the relevant INA provisions ask what the noncitizen was 'convicted of,' not what he did, and the inquiry in immigration proceedings is limited accordingly." 37

In Moncrieffe, the Court rejected the Government's proposal that noncitizens "be given an opportunity during immigration proceedings to demonstrate that their predicate marijuana distribution convictions involved only a small amount of marijuana and no remuneration, just as a federal criminal defendant could do at sentencing." 38 The Court explained that the Government's proposal "would require precisely the sort of post hoc investigation into the facts of predicate offenses that we have long deemed undesirable." ${ }^{39}$ The Court emphasized that "[t]he categorical approach serves 'practical' purposes: It promotes judicial and administrative efficiency by precluding the relitigation of past convictions in minitrials conducted long after the fact." 40 Under the Government's proposal, "two noncitizens, each 'convicted of' the same offense, might obtain different aggravated felony determinations depending on what evidence remains available or how it is perceived by an individual immigration judge," which the Court described as precisely the type of "potential unfaimess" that the categorical approach was designed to avoid. ${ }^{41}$

Just two months after issuing its decision in Moncrieffe, the Supreme Court issued its opinion in Descamps $v$. United States, ${ }^{42}$ also addressing the categorical approach but arising under the Armed Career Criminal Act ("ACCA") instead of the INA. ${ }^{43}$ Descamps resolved a circuit split by holding that the modified categorical approach only applies to divisible statutes. ${ }^{44}$ The Court found that the modified categorical approach does not apply to California's burglary

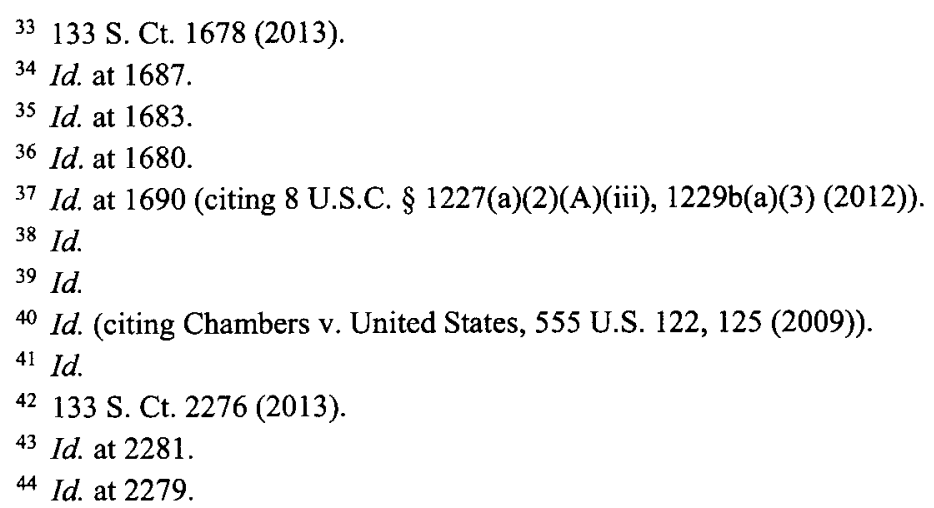


statute, which is missing the element of unlawful entry that is required for a generic federal burglary offense. ${ }^{45}$ The Court explained that a jury must find facts about a defendant's underlying conduct unanimously and beyond a reasonable doubt, "[a]nd the only facts the court can be sure the jury so found are those constituting elements of the offense-as distinct from amplifying but legally extraneous circumstances." 46 The Court noted that a defendant "often has little incentive to contest facts that are not elements of the charged offense-and may have good reason not to," because extraneous facts and arguments may just confuse the jury at trial or "irk the prosecutor or court" during plea hearings. ${ }^{47}$

In addition, the Court was concerned about "depriv[ing] some defendants of the benefits of their negotiated plea deals." 48 The Court reasoned that if a defendant surrenders his right to trial in exchange for the Government's agreement that he plead guilty to a less serious crime, it would be unfair to later treat the defendant as if he had pled guilty to the original charge, since that would be letting a court "rewrite the parties' bargain."49 Because the California burglary statute under which Matthew Descamps was convicted did not require the factfinder to determine whether there was an unlawful entry, the Supreme Court held that a conviction under that statute is never for generic burglary and that the Court of Appeals for the Ninth Circuit had erred in "look[ing] behind Descamps' conviction in search of record evidence that he actually committed the generic offense." 50

The Supreme Court also addressed the categorical approach in its 2012 decision in Kawashima $v$. Holder, ${ }^{51}$ which involved the aggravated felony provision under the INA pertaining to a conviction that "involves fraud or deceit in which the loss to the victim or victims exceeds $\$ 10,000 . " 52$ Akio Kawashima had been convicted of filing a materially false corporate tax return, and his wife, Fusako Kawashima, had been convicted of knowingly and willfully assisting him. ${ }^{53}$ In determining whether their convictions necessarily "involve[d] fraud or deceit," the Court employed the categorical approach, explaining that "[i]f the elements of the offenses establish that the Kawashimas committed crimes involving fraud or deceit, then [the clause] is satisfied." 54 Because the elements of the crimes of conviction required the document to be false as to a material

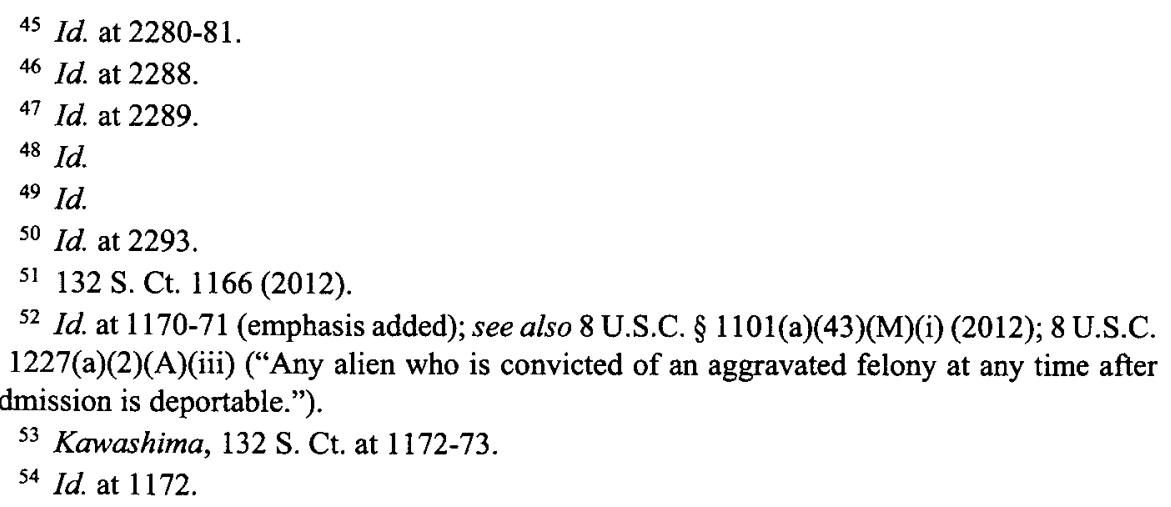


matter and the defendant to have acted willfully, the Court found that the convictions necessarily involved fraud or deceit, even though the words "fraud" or "deceit" did not appear in the statutory text. ${ }^{55}$

The decision in Kawashima, along with the other cases discussed above, cast doubt on a 2008 opinion issued by Attorney General Mukasey in the Matter of Silva-Trevino ("Silva-Trevino I"), ${ }^{56}$ which addressed how to determine if a noncitizen had been "convicted of . . . a crime involving moral turpitude" under the INA. ${ }^{57}$.This moral turpitude provision used the word "involve," just like the aggravated felony ground addressed in Kawashima. But, unlike the Supreme Court, the Attorney General's opinion had permitted the BIA and immigration judges to go beyond the categorical and modified categorical approaches and look at evidence outside the record of conviction to determine if the crime involved moral turpitude. ${ }^{58}$

In April 2015, Attorney General Holder vacated the 2008 decision in SilvaTrevino I in light of the Supreme Court's decisions in Kawashima, CarachuriRosendo, and Moncrieffe. ${ }^{59}$ By that time, a circuit split had already developed about whether the approach set forth in Silva-Trevino I deserved deference from the federal appellate courts. ${ }^{60}$ The five appellate courts that had rejected SilvaTrevino I's approach stressed that Congress's use of the word "convicted" in the statutory phrase "convicted ... of a crime involving moral turpitude" prohibited immigration judges from inquiring into relevant evidence outside the record of conviction. ${ }^{61}$ In his April 2015 opinion ("Silva-Trevino II"), Attorney General Holder also recognized that recent Supreme Court decisions "reaffirmed that the phrase "convicted of' required a categorical approach."62

$55 \mathrm{Id}$. at 1172-73.

${ }^{56} 24$ I. \& N. Dec. 687, 689 (Att'y Gen. 2008), overruled by 26 I. \& N. Dec. 550 (Att'y Gen. 2015).

578 U.S.C. $\S 1182(a)(2)(A)(i)$ (emphasis added); Silva-Trevino, 24 I. \& N. Dec. at 689.

${ }^{58}$ Silva-Trevino, 24 I. \& N. Dec. at 704.

${ }^{59}$ Silva-Trevino, 26 I. \& N. Dec. at 553.

${ }^{60} \mathrm{Id}$. (commenting that one reason for reevaluating the 2008 decision was because of the disagreement among the circuits); see also Silva-Trevino v. Holder, 742 F.3d 197, 200-06 (5th Cir. 2014) (rejecting the Attorney General's opinion and finding that the statute was not ambiguous); Olivas-Motta v. Holder, 746 F.3d 907, 911-16 (9th Cir. 2014) (as amended) (same); Prudencio v. Holder, 669 F.3d 472, 480-84 (4th Cir. 2012) (same); Fajardo v. U.S. Att'y Gen., 659 F.3d 1303, 1307-11 (11th Cir. 2011) (same); Jean-Louis v. U.S. Att'y Gen., 582 F.3d 462, 472-82 (3d Cir. 2009) (same). But see Bobadilla v. Holder, 679 F.3d 1052, 1057-58 (8th Cir. 2012) (giving deference to the Attorney General's interpretation and remanding for a determination under that standard); Mata-Guerrero v. Holder, 627 F.3d 256, 260-61 (7th Cir. 2010) (same).

${ }^{61}$ Silva-Trevino, 742 F.3d at 200-01, $201 \mathrm{n} .1$; see also Pooja R. Dadhania, Note, The Categorical Approach for Crimes Involving Moral Turpitude After Silva-Trevino, 111 Colum. L. REV. 313, 340-46 (2011) (discussing the circuit split that resulted from SilvaTrevino and arguing for a uniform categorical approach to safeguard noncitizens).

62 Silva-Trevino, 26 I. \& N. Dec. at 553. 
Subsequently, in June 2015, the Supreme Court issued its decision in Mellouli v. Lynch ${ }^{63}$ and applied the categorical approach in determining whether a Kansas conviction for possession of drug paraphernalia constituted a controlled substance conviction under the INA. ${ }^{64}$ The only piece of "paraphernalia" in that case was a sock that contained a few unidentified tablets. ${ }^{65}$ After discussing the origins of the categorical approach, the Court stressed that it is "[r]ooted in Congress' specification of conviction, not conduct, as the trigger for immigration consequences." 66 The Court also highlighted the practical benefits of the categorical approach, noting that it is "suited to the realities of the system." ${ }^{67}$ Relying on two excellent scholarly articles by Alina Das and Jennifer Koh, the Court explained that immigration judges are overloaded with cases, and that the categorical approach promotes efficiency, fairness, and predictability. The categorical approach allows noncitizens to anticipate the consequence of a conviction and thereby enter into "safe harbor" pleas that do not expose them to the risk of removal. ${ }^{68}$

These decisions all emphasize that the use of the word "convicted" triggers the categorical approach when interpreting the criminal grounds of deportability and bars to relief from removal in the INA. But there is one striking exception: the categorical approach has not been applied in analyzing whether a noncitizen has been "convicted" of a "particularly serious crime," which is a bar to both asylum and withholding of removal. ${ }^{69}$ The following Section provides some basic background information about this bar and then explains how the BIA's approach to the particularly serious crime determination deviates from a categorical analysis.

\section{B. Conviction for a "Particularly Serious Crime"}

A noncitizen who satisfies the definition of a refugee by demonstrating a wellfounded fear of persecution on account of race, religion, nationality, membership in a particular social group, or political opinion can still be deported to his or her home country if it is determined that "the alien, having been convicted by a final judgment of a particularly serious crime is a danger to the community of the United States." 70 The particularly serious crime bar applies to

${ }^{63} 135$ S. Ct. 1980 (2015).

${ }^{64}$ Id. at $1983-84$.

${ }^{65} \mathrm{Id}$. at 1984.

${ }^{66} I d$. at 1986 (emphasis added).

67 Id.

${ }^{68}$ Id. at 1986-87 (citing Das, supra note 12, at 1725-42, 1737-78; Jennifer Lee Koh, The Whole Better than the Sum: A Case for the Categorical Approach to Determining the Immigration Consequences of Crime, 26 GEO. IMMIGR. L.J. 257, 295 (2012)).

698 U.S.C. $\S 1158($ b)(2)(A)(ii) (2012) (refusing to grant asylum to aliens convicted of a particularly serious crime); 8 U.S.C. $§ 1231$ (b)(3)(B)(ii) (describing withholding of removal for aliens convicted of a particularly serious crime).

${ }^{70} 8$ U.S.C. $\S 1231($ b)(3)(B)(ii) (emphasis added). 
both asylum and withholding of removal. ${ }^{71}$ These are similar forms of relief, but there are some important differences.

While asylum is discretionary, withholding of removal is mandatory, reflecting the obligation of nonrefoulement under the Refugee Convention and Protocol. ${ }^{72}$ To obtain withholding of removal, a noncitizen must demonstrate a higher likelihood of future persecution if deported than for asylum. Asylum requires only a reasonable chance of future persecution, which can be a ten percent chance, but withholding of removal requires a greater than fifty percent chance of future persecution, setting a much higher standard. ${ }^{73}$ In 2014, immigration courts granted only twelve percent of applications for withholding of removal, compared to forty-nine percent for asylum. ${ }^{74}$ One advantage of withholding of removal is that there is no deadline to apply, whereas an asylum application must normally be filed within one year of entering the United States. ${ }^{75}$ The major disadvantage of withholding of removal is that, unlike asylum, it does not put someone on a path to lawful permanent residency and citizenship. ${ }^{76}$ It simply prevents deportation to the country of feared persecution and makes the person eligible for a work permit. ${ }^{77}$ If someone who has been granted withholding of removal travels outside the United States, he or she will have no status with which to reenter the country. ${ }^{78}$

71 Id. (describing withholding of removal); see also 8 U.S.C. $\$ 1158(\mathrm{~b})(2)(\mathrm{A})(\mathrm{ii})$ ("[T]he alien, having been convicted by a final judgment of a particularly serious crime, constitutes a danger to the community of the United States." (emphasis added)).

72 See INS v. Doherty, 502 U.S. 314, 332 (1992) ("Because of the mandatory nature of the withholding-of-deportation provision, the Attorney General's power to deny withholding claims differs significantly from his broader authority to administer discretionary forms of relief such as asylum ....").

${ }^{73}$ Compare 8 C.F.R. $\S 208.16(\mathrm{~b})(2)$ (2017) (applying the "more likely than not" standard to withholding of removal), with INS v. Cardoza-Fonseca, 480 U.S. 421, 440 (1987) (holding that even a ten percent chance of future persecution is a reasonable possibility that satisfies the standard for asylum).

74 U.S. DEP'T OF JUSTICE, EXEC. OFFICE FOR IMMIGRATION REVIEW, FY 2014 STATISTICS $\begin{array}{llll}\text { YEARBOOK, } & \text { at } & \text { K1, } 5 & \text { (2015), }\end{array}$ http:/www.justice.gov/sites/default/files/eoir/pages/attachments/2015/03/16/fy14syb.pdf

[https://perma.cc/2VV-65VX]. Asylum applications that were filed affirmatively with the Department of Homeland Security's U.S. Citizenship and Immigration Services ("USCIS") and then referred to immigration court had a grant rate of seventy-five percent in 2014 , compared to a grant rate of just twenty-eight percent for asylum applications filed with the immigration court defensively. $I d$. at $\mathrm{K} 3$. The forty-nine percent overall grant rate includes asylum applications in both categories.

75 See 8 C.F.R. $\S 1208.4(a)$; see also Oroh v. Holder, 561 F.3d 62, 66 (1st Cir. 2009).

${ }^{76}$ See Vrljicak v. Holder, 700 F.3d 1060, 1061 (7th Cir. 2012) (stating that withholding of removal does not give all the benefits of asylum).

77 See 8 C.F.R. $§ 1208.7$ (allowing aliens who are granted withholding of removal to apply for employment authorization).

78 See 8 C.F.R. $\S 1208.8$. 
Congress has specified in the INA that certain convictions are per se particularly serious crimes. The INA provides that any aggravated felony conviction is a particularly serious crime that bars asylum, and one or more aggravated felony convictions with an aggregate sentence of at least five years is a particularly serious crime barring withholding of removal. ${ }^{79}$ Congress set a higher standard for a crime to be per se "particularly serious" in the context of withholding of removal in order to avoid potential violations of the international obligation of nonrefoulement. ${ }^{80}$ Because courts routinely use the categorical approach in determining whether a conviction is an aggravated felony, this approach is applied in deciding whether a conviction is per se particularly serious under the INA.

However, the BIA and many courts of appeals have held that particularly serious crimes are not limited to aggravated felonies, and for those convictions, the BIA has created its own test that does not apply the categorical approach, despite the use of the word "convicted" in the statute. ${ }^{81}$ This makes the particularly serious crime bar the only bar to relief based on a conviction that does not involve the categorical approach.

The Supreme Court has explained that the categorical approach applies where "Congress intended that [a certain statutory] provision be triggered by crimes having certain specified elements." 82 As the Ninth Circuit has explained, "[i]n the immigration context, this approach therefore generally applies in determining whether an alien is removable in the first instance or whether he is statutorily barred from various forms of relief."83 The court contrasted "questions of statutory removability and eligibility for relief" with discretionary

798 U.S.C. $\S 1231$ (b)(3)(B) (2012) (“[A]n alien who has been convicted of an aggravated felony (or felonies) for which the alien has been sentenced to an aggregate term of imprisonment of at least 5 years shall be considered to have committed a particularly serious crime."); 8 U.S.C. $\S 1158$ (b)(2)(B)(i) ("[A]n alien who has been convicted of an aggravated felony shall be considered to have been convicted of a particularly serious crime.").

${ }^{80}$ In 1990, Congress made every aggravated felony a particularly serious crime that barred a noncitizen from receiving withholding of removal. See 8 U.S.C. $\S 1253(\mathrm{~h})(2)(B)(1994)$ (amended 1996). On April 24, 1996, Congress enacted Section 413(f) of the Antiterrorism and Effective Death Penalty Act of 1996, Pub. L. No. 104-132, 110 Stat. 1214 ("AEDPA"), which amended former 8 U.S.C. $\S 1253(\mathrm{~h})$ to give the Attorney General discretionary authority to override the categorical bar that designated any aggravated felony a particularly serious crime, if necessary, to comply with the nonrefoulement obligation under the Protocol. Several months later, on September 30, 1996, Congress enacted Section 305(a) of the Illegal Immigration Reform and Immigrant Responsibility Act of 1996, Pub. L. No. 104-208, div. C, 110 Stat. 3009-546 ("IIRIRA"), which again amended 8 U.S.C. $\$ 1253(\mathrm{~h})$ and recodified it as 8 U.S.C. $\$ 1231$ (b)(3)(B)(ii), effective as of April 1, 1997.

${ }^{81}$ In re N-A-M-, 24 I. \& N. Dec. 336, 344-45 (B.I.A. 2007).

82 Taylor v. United States, 495 U.S. 575, 588 (1990) (discussing the categorical approach in the context of the Armed Career Criminal Act).

${ }^{83}$ Torres-Valdivias v. Lynch, 786 F.3d 1147, 1152 (9th Cir. 2015). 
determinations, such as whether to grant an application for adjustment of status, which is the process of becoming a lawful permanent resident. ${ }^{84}$

Although the failure to apply the categorical approach to the particularly serious crime bar is a striking anomaly, it has received little attention from the BIA or federal courts. In a 2007 case predating Carachuri-Rosendo, Kawashima, Moncrieffe, Descamps, and Mellouli, the BIA stated in In re N-A$M$-, "[no] decision of which we are aware, has ever suggested that the categorical approach, used primarily in determining removability, is applicable to the inherently discretionary determination of whether a conviction is for a particularly serious crime." 85 This statement was dicta because the BIA did not make a legal finding that the categorical approach does not apply. In fact, the BIA pointed out that the respondent in that case had not even argued that the categorical approach should be applied. ${ }^{86}$

Nevertheless, two courts of appeals have relied on the BIA's dicta in finding that the categorical approach does not apply to the particularly serious crime determination. The Ninth Circuit cited the BIA's decision without any discussion. ${ }^{87}$ The Court of Appeals for the Third Circuit agreed, relying on the BIA's rationale that the particularly serious crime determination is discretionary ${ }^{88}$ The court found that "there are no textual or contextual indicators in the INA as to "how the Board should determine whether an alien has committed a particularly serious crime," except for the statutory provision pertaining to aggravated felony convictions. ${ }^{89}$ The Third Circuit did not explain why the word "convicted" in the statute, which Carachuri-Rosendo had described as a "statutory hook," does not serve as a textual indicator that triggers the categorical approach..$^{90}$ Because the Third Circuit's decision predated Kawashima, Moncrieffe, Descamps, and Mellouli, the court did not have the benefit of those decisions hammering home the significance of the word "convicted." As of the date of this writing, no other circuits have addressed this issue. 91

${ }^{84} I d$.

${ }^{85} N-A-M-, 24$ I. \& N. Dec. at 344 (emphasis added).

86 Id. at $344-45$.

87 Anaya-Ortiz v. Holder, 594 F.3d 673, 680 (9th Cir. 2010).

${ }^{88}$ Denis v. Att'y Gen. of the United States, 633 F.3d 201, 214-15 (3d Cir. 2011).

${ }^{89}$ - Id. at 214 (quoting Chong v. INS, 264 F.3d 378, 387 (3d Cir. 2001)) (internal quotations omitted).

90 See id.

91 In an unpublished decision where the petitioner argued that the immigration judge and BIA erred by considering evidence outside the record of conviction, the Sixth Circuit explained that the BIA's test in $N$ - $A$ - $M$ - permitted this. Hernandez-Vasquez v. Holder, $430 \mathrm{~F}$. App'x 448, 452 (6th Cir. 2011) (citing $N-A-M-, 24$ I. \& N. Dec. at 344). The court also quoted the language in $N-A-M$-, noting that the BIA was not aware of any cases suggesting that the categorical approach is applicable to the particularly serious crime determination, although it does not rely on that language. See id. 
There are several reasons to question the BIA's characterization of the particularly serious crime bar as "inherently discretionary."92 In an earlier decision where the BIA refused to apply the principle of proportionality to the particularly serious crime determination, it reasoned that this principle would "transform a statutory exclusionary clause into a discretionary consideration." Clearly, the BIA did not consider the particularly serious crime determination discretionary at that time. In a subsequent case, the BIA reiterated, "the statutory exclusionary clause for a 'particularly serious crime' relates only to the nature of the crime itself and that it does not vary with the nature of the evidence of persecution." 94 Both of these decisions, which pre-date any convictions being classified as per se particularly serious by the INA, use the term "statutory exclusionary clause" to emphasize that the determination is not discretionary.

Furthermore, the text of the INA does not specify that the particularly serious crime bar is discretionary. The statute provides that a noncitizen is ineligible for withholding of removal if "the Attorney General decides that ... the alien, having been convicted by a final judgment of a particularly serious crime is a danger to the community of the United States." ${ }^{95}$ For the parallel provision regarding asylum, the statute uses the word "determines" in lieu of "decides." Several courts of appeals have held that the words "decides" and "determines" in these statutory provisions do not specify that the decisions are discretionary. ${ }^{97}$ Otherwise, the courts would not have jurisdiction over the particularly serious crime determination, because the INA strips the federal appellate courts of

${ }_{92}$ But see $N-A-M-, 24$ I. \& N. Dec. at 344.

${ }^{93}$ In re Rodriguez-Coto, 19 I. \& N. Dec. 208, 209 (B.I.A. 1985).

94 In re Garcia-Garrocho, 19 I. \& N. Dec. 423, 424-25 (B.I.A. 1986).

958 U.S.C. $\S 1231$ (b)(3)(B) (2012) (emphasis added).

968 U.S.C. $\S 1158$ (b)(2)(A) ("Paragraph (1) shall not apply to an alien if the Attorney General determines that ...." (emphasis added)).

97 See, e.g., Arbid v. Holder, 700 F.3d 379, 384 (9th Cir. 2012) (per curiam); Delgado v. Holder, 648 F.3d 1095, 1100 (9th Cir. 2011) (interpreting the Supreme Court's decision in Kucana v. Holder, 558 U.S. 233 (2010), to mean that 8 U.S.C. $\S 1252$ (a)(2)(B)(ii) only bars review of a discretionary decision when the statute explicitly refers to the decision of the Attorney General); Berhane v. Holder, 606 F.3d 819, 821-22 (6th Cir. 2010) (“[E]mpowering the Attorney General to 'determine[]' (or for that matter 'decide[]') something no more 'specif[ies]' 'discretion' than empowering the Attorney General to exercise any number of responsibilities under the Act, be they interpretations of the Act, adjudications under the Act, the adoption of rules under the Act or anything else that might count as an administrative 'determination' under the Act." (alterations in original)); Nethagani v. Mukasey, 532 F.3d $150,154-55$ (2d Cir. 2008) (holding that the INA does not expressly place the particularly serious crime determination within the discretion of the Attorney General, so the court retains jurisdiction to review that determination); Alaka v. Att'y Gen. of the United States, 456 F.3d 88, 96-100 (3d Cir. 2006) (holding that "the terms 'decide[]' or 'determin[e]"' that precede the bars to withholding of removal "are not, standing alone, sufficient to 'specify' discretion"). 
jurisdiction over decisions "specified" by statute to be in the Attorney General's discretion. ${ }^{98}$

In holding that this jurisdictional bar did not apply, the Third Circuit reasoned in Alaka v. Attorney General of the United States that the statute contains no explicit reference to "discretion" and does not use the word "may." 99 Furthermore, the court stressed that withholding of removal is mandatory when someone's life or freedom would be threatened, and "[a]ny evaluation of the 'discretionary' nature of the 'particularly serious crime' determination should be conducted in light of the mandatory character of withholding." 100 The court also contrasted the particularly serious crime bars with dozens of other INA provisions that explicitly refer to discretion; it concluded that "[i]f Congress had wanted to specify the discretion to make the 'particularly serious' determination, it would have employed the same explicit language used in other provisions of the same statute." 101 The Courts of Appeals for the Second and Sixth Circuits have reached the same conclusion. ${ }^{102}$

In a 2012 decision, the Ninth Circuit agreed that the INA does not "specify" that the particularly serious crime decision is discretionary, reversing its earlier position and resolving a circuit split in light of a Supreme Court decision that clarified the meaning of the INA's jurisdictional bar on discretionary decisions. ${ }^{103}$ However, even though the Ninth Circuit now agrees that the particularly serious crime determination is reviewable, it has decided that the proper standard of review is "abuse of discretion."104 But appellate courts have not consistently reviewed this determination under the abuse of discretion standard. There are inconsistencies among and within circuits as to the proper standard of review for the particularly serious crime determination. Some courts apply abuse of discretion, while others apply de novo, a combination of de novo and Chevron deference, or substantial evidence. The different standards of review reflect confusion over whether the particularly serious crime determination is a legal conclusion, a mixed question of law and fact, a factual finding, or an entirely discretionary decision.

Although the Ninth Circuit adopted the abuse of discretion standard in Arbid v. Holder, in prior decisions it has applied de novo review, or de novo with

988 U.S.C. $\$ 1252(\mathrm{a})(2)(\mathrm{B})(\mathrm{ii})$ (stating that no court has the jurisdiction to review any "decision" of the Attorney General in removal proceedings).

99 Alaka, 456 F.3d at 97-100 ("By way of contrast, Congress knows how to 'specify' discretion and has done so repeatedly in other provisions of the INA.").

$100 \mathrm{Id}$. at 100.

101 Id. at 98.

102 Berhane, 606 F.3d at 821-22; Nethagani, 532 F.3d at 154-55 (finding that because of a strong presumption in favor of judicial review, the Attorney General only has discretion when the statute is explicit).

103 See Arbid v. Holder, 700 F.3d 379, 383-85 (9th Cir. 2012) (per curiam); Delgado v. Holder, 648 F.3d 1095, 1100 (9th Cir. 2011).

104 Arbid, 700 F.3d at 385. 
deference to the BIA's interpretation under Chevron, to the particularly serious crime determination. ${ }^{105}$ The Third Circuit has held that "whether [an alien] was convicted of a 'particularly serious crime' is a question of law reviewed de novo, albeit with deference to the agency where appropriate." 106 The Sixth Circuit has explained that the particularly serious crime determination involves "the application of law to fact" and therefore receives de novo review, although under Chevron the court must "defer to an agency's reasonable interpretation of a statute it administers unless 'the intent of Congress is clear." 107 In older published decisions, the Courts of Appeals for the Fourth and Fifth Circuits have treated the particularly serious crime determination as a factual conclusion and reviewed it for substantial evidence. ${ }^{108}$ Yet in more recent unpublished

105 See id. (applying abuse of discretion standard). But see Perez-Palafox v. Holder, 744 F.3d 1138, 1145 (9th Cir. 2014) ("We have consistently held that application of the Frentescu factors to the underlying facts is a legal conclusion and not a fact-finding endeavor." (citing Afridi v. Gonzalez, 442 F.3d 1212, 1219 (9th Cir. 2006)); Luan v. INS, No. 96-70323, 1997 WL 599665, at *1 (9th Cir. Sept. 23, 1997) ("We review de novo whether an offense is a particularly serious crime ....”); Mustafa v. INS, No. 93-70038, 1994 WL 65944, at *1 (9th Cir. Mar. 1, 1994) ("We review de novo the question of whether Mustafa's offenses constitute 'particularly serious crimes' but with deference to the INS' interpretation of that term in its regulations."); Tran v. INS, No. 92-70399, 1993 WL 420820, at *1 (9th Cir. Oct. 20, 1993) ("We review de novo the question of whether Tran's offenses constitute 'particularly serious crimes' but with deference to the BIA's interpretation of the statute."); Beltran-Zavala v. INS, 912 F.2d 1027, 1029 (9th Cir. 1990) ("Whether an offense is a particularly serious crime under Section $243(\mathrm{~h})(2)(\mathrm{B})$ of the INA is reviewed de novo, but with deference to the INS' interpretation of that term in its regulations."). Despite the Immigration Act of 1990, which made all aggravated felonies per se particularly serious crimes during this period, the BIA continued to adjudicate particularly serious crimes on a case-by-case basis between 1990 and 1996. See Delgado, 648 F.3d at 1104; In re B-, 20 I. \& N. Dec. 427, 430-31 (B.I.A. 1991).

${ }^{106}$ Infante v. Att'y Gen. of the United States, 574 F. App'x 142, 145 (3d Cir. 2014); see also Denis v. Att'y Gen. of the United States, 633 F.3d 201, 205-06 (3d Cir. 2011) ("Denis contends that his crime of conviction... should not constitute a particularly serious crime.... [This] assertion implicates 'constitutional claims or questions of law,' and we review the BIA's legal determinations de novo, subject to Chevron principles of deference." (citation omitted)); Lavira v. Att'y Gen. of the United States, 478 F.3d 158, 164 (3d Cir. 2007) (holding that whether an alien has been convicted of a particularly serious crime is a question of law reviewed de novo), overruled on other grounds by Pierre v. Att'y Gen. of the United States, 528 F.3d 180, 189 (3d Cir. 2008) (en banc).

107 Hamama v. INS, 78 F.3d 233, 239 (6th Cir. 1996) (internal quotations omitted).

108 See Mejia v. INS, No. 96-60655, 1997 WL 450111, at *3 (5th Cir. July 9, 1997) ("Mejia pleaded guilty to striking a police officer after Mejia 'knew and had been informed that [Officer Pagan] was a peace officer,' which was a crime against a person that constitutes a flagrant disregard for authority. There was substantial evidence to support the ruling of the BIA."); Karapetyan v. INS, No. 95-1103, 1995 WL 522573, at *1 (4th Cir. Sept. 6, 1995) ("Substantial evidence supports the finding that this constituted a conviction of a "particularly serious crime' precluding the withholding of deportation and mandating the denial of asylum."); Sam v. INS, No. 93-5019, 1994 WL 57627, at *1 (5th Cir. Feb. 17, 1994) (per curiam) ("[O]ur review of the BIA's factual conclusion that Sam was convicted of a 
decisions, the Fourth and Fifth Circuits have applied abuse of discretion. ${ }^{109}$ The Court of Appeals for the Seventh Circuit has held that abuse of discretion is the proper standard of review, unless the claim is that the BIA failed to apply the "right rule of law when making the classification."110 This approach resembles the Ninth Circuit's current approach, as the Ninth Circuit has explained that it will not "re-weigh" a discretionary determination but it will review de novo a legal issue, such as whether the BIA applied the correct legal standard. ${ }^{111}$ The Courts of Appeals for the Second, Eighth, and Tenth Circuits have applied abuse of discretion in unpublished decisions. ${ }^{112}$ The inconsistent application of the standards of review indicates that most courts have not explicitly grappled with the issue of whether or not the particularly serious crime bar is discretionary, much less examined the related question of whether the categorical approach should apply.

In addition, classifying the particularly serious crime determination as discretionary conflicts with how courts have treated other bars to withholding of removal in the same section of the statute. For example, the clause immediately following the particularly serious crime bar applies if "there are serious reasons to believe that the alien committed a serious nonpolitical crime outside the United States before the alien arrived in the United States." 113 This bar does not require a conviction, but it is reviewed under a more probing standard than abuse of discretion. Courts have applied the substantial evidence standard in examining the BIA's factual findings regarding the criminal nature of the act

particularly serious crime is guided by the familiar 'substantial evidence' standard.").

${ }^{109}$ See, e.g., Lozano-Bolanos v. Holder, 588 F. App'x 272, 272 (4th Cir. 2014) (per curiam) (concluding that "the Board did not abuse its discretion in finding that LozanoBolanos was convicted of a particularly serious crime"); Solorzano-Moreno v. Mukasey, 296 F. App'x 391, 394 (5th Cir. 2008) (finding that the petitioner's arguments about the particularly serious crime determination "amount to an argument that the immigration judge 'abused [her] discretion in weighing the multiple desiderata made relevant by the [BIA's] definition of a 'particularly serious crime"' (quoting Petrov v. Gonzales, 464 F.3d 800, 802 (7th Cir. 2006))).

110 Petrov, 464 F.3d at 802 (citing Tunis v. Gonzales, 447 F.3d 547, 549 (7th Cir. 2006)).

111 Konou v. Holder, 750 F.3d 1120, 1127 (9th Cir. 2014) ("Although we cannot reweigh evidence to determine if the crime was indeed particularly serious, [we] can determine whether the BIA applied the correct legal standard."); Pechenkov v. Holder, 705 F.3d 444, 448-49 (9th Cir. 2012) ("Petitioner has not raised a constitutional or legal question in relation to the 'particularly serious crime' determination; instead, he asks for a re-weighing of the factors involved in that discretionary determination.").

112 Hassan v. Holder, 446 F. App'x 822, 823 (8th Cir. 2012) (per curiam) ("Upon review, we conclude that the BIA did not abuse its discretion in determining that Hassan was ineligible for withholding of removal because he had been convicted of a particularly serious crime and was a danger to the community."); Akrami v. Chertoff, 186 F. App'x 47, 50 (2d Cir. 2006) ("[T]he [immigration judge] did not abuse her discretion in finding that Akrami was also barred from withholding, having been convicted of a particularly serious crime.").

1138 U.S.C. $\S 1231$ (b)(3)(B)(iii) (2012). 
and the political motive for the actions. ${ }^{114}$ Some courts have also applied the Chevron doctrine to review the BIA test for a "serious nonpolitical crime" by examining whether the criminal nature of the offense is "outweighed" by its political nature. ${ }^{15}$ Similarly, courts have applied the substantial evidence standard of review to another bar that applies if the noncitizen has engaged in the persecution of others. ${ }^{116}$

Because the particularly serious crime bar, like the serious nonpolitical crime bar and the persecution of others bar, usually involves factual findings about the circumstances surrounding a crime, those findings should be reviewed under the substantial evidence standard, rather than for abuse of discretion. Furthermore, the BIA's current test combines this factual inquiry with an examination of the elements of the offense, giving the test a legal dimension as well. Indeed, the BIA has stressed that " $t$ t] he language of the statute provides the 'essential key' to determining whether a crime is particularly serious," and it has held that some offenses can be deemed particularly serious based on their elements alone. ${ }^{117}$ Errors involving the interpretation of the elements of an offense are normally considered legal questions and reviewed de novo. ${ }^{118}$ The BIA's emphasis on the

114 See, e.g., Zheng v. Holder, 698 F.3d 710, 713-14 (8th Cir. 2012) (finding substantial evidence that Zheng's attack against a family planning official in China, resulting in serious physical injury, was a serious nonpolitical crime, based on the immigration judge's findings that the assault was not a political response to China's family planning policy, but was motivated by the official's refusal to return Zheng's property); Go v. Holder, 640 F.3d 1047, 1052-53 (9th Cir. 2011) (applying the substantial evidence standard to uphold the lower court's ruling that Go's drug trafficking activities prior to entering United States constituted a serious nonpolitical crime); Berhane v. Holder, 606 F.3d 819, 823 (6th Cir. 2010) (applying the substantial evidence standard in reviewing the BIA's determination that throwing rocks at the police during demonstrations in Ethiopia constituted a "serious nonpolitical crime"); Urbina-Mejia v. Holder, 597 F.3d 360, 369-70 (6th Cir. 2010) (applying the substantial evidence standard to find that Urbina-Mejia's gang activity in his native country of Honduras, which included attacking a man with a baseball bat and extorting people for money, was a serious nonpolitical crime); Wang v. Holder, 583 F.3d 86, 91 (2d Cir. 2009) (applying the substantial evidence standard in holding that participation in a scheme to deceive prisoners and their families and to sell organs on the black market was a serious nonpolitical crime).

115 Berhane, 606 F.3d at 823-35 (applying the Chevron doctrine and holding that the BIA had not exercised "reasoned discretion" in its treatment of rock throwing as a serious nonpolitical crime and in disregarding arguments about self-defense).

116 See 8 U.S.C. $\S 1231(\mathrm{~b})(3)(B)(i)$. For cases applying substantial evidence review to the persecution of others bar, see Castañeda-Castillo v. Holder, 723 F.3d 48, 53-54 (1st Cir. 2013); Ntamack v. Holder, 372 F. App'x 407, 411 (4th Cir. 2010) (per curiam); Parlak v. Holder, 578 F.3d 457, 470 (6th Cir. 2009); Miranda Alvarado v. Gonzales, 449 F.3d 915, 929 (9th Cir. 2006); Zheng v. BIA, 119 F. App'x 321, 323 (2d Cir. 2005).

117 In re G-G-S-, 26 I. \& N. Dec. 339, 344 (B.I.A. 2014) (emphasis added).

118 See, e.g., United States v. Boyle, 469 U.S. 241, 249 n.8 (1985) ("Whether the elements that constitute 'reasonable cause' are present in a given situation is a question of fact, but what elements must be present to constitute 'reasonable cause' is a question of law."); United States v. Pitrone, 115 F.3d 1, 4 (1st Cir. 1997) (explaining that when an error "involves the 
elements of the offense supports the position that the particularly serious crime determination is not purely discretionary. If the federal courts ultimately agree that the particularly serious crime determination is not discretionary, then the categorical approach should certainly be applied. However, even if they conclude that it is discretionary, the BIA could decide on its own to apply the categorical approach to the particularly serious crime determination.

The following Section discusses in detail the BIA's current test for whether a conviction constitutes a particularly serious crime. This discussion shows how it conflates certain aspects of the categorical approach with the type of factual inquiry that is strictly prohibited under that approach. The Article argues that the result is unworkable because it creates an overly expansive exception to the international nonrefoulement obligation and leads to arbitrary and unpredictable decisions about which convictions will become bars to asylum and withholding of removal.

\section{The BIA's Quasi-Categorical Approach}

In 1982, eight years before the INA included any statutory classifications of certain offenses as particularly serious crimes, the BIA issued its decision in the Matter of Frentescu, ${ }^{119}$ which addressed the particularly serious crime determination. The BIA explained, "[w]hile there are crimes which, on their face, are 'particularly serious crimes' or clearly are not 'particularly serious crimes,' the record in most proceedings will have to be analyzed on a case-bycase basis." 120 Thus, the BIA found that some convictions could be deemed per se particularly serious by immigration judges, while others would require an individualized inquiry. ${ }^{121}$ The BIA then provided four factors to consider in that analysis, which include "the nature of the conviction, the circumstances and underlying facts of the conviction, the type of sentence imposed, and, most importantly, whether the type and circumstances of the crime indicate that the alien will be a danger to the community." 122

Several years later, the BIA held in the Matter of Carballe ${ }^{123}$ that a separate assessment of dangerousness is not required for the particularly serious crime bar to apply. ${ }^{124}$ The BIA interpreted the statutory provision as establishing a cause-and-effect relationship between the conviction and the danger. ${ }^{125}$ In other words, the conviction for a particularly serious crime is what demonstrates that the noncitizen poses a danger to the community. Carballe explained that the

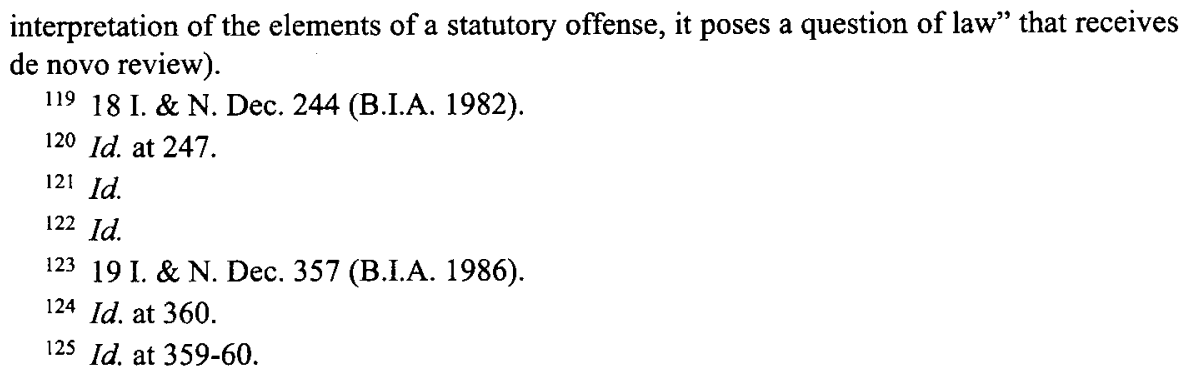


"essential key" to this inquiry is the nature of the crime, meaning the elements of the offense. ${ }^{126}$ In holding that robbery and attempted robbery are particularly serious crimes based on their elements alone, this decision also reinforced the principle first mentioned in Frentescu, that some crimes are particularly serious on their face.

In subsequent cases, the BIA classified additional offenses as per se particularly serious crimes, such as drug trafficking and burglary involving a dangerous weapon or resulting in physical injury. ${ }^{127}$ In In re Q-T-M-T-, ${ }^{128}$ the BIA confirmed that "a consistent practice of this Board has been to classify certain crimes as per se 'particularly serious crimes' on their face without proceeding to an individualized examination of the Frentescu factors." 129 Yet the BIA did not consistently apply its own rules, leading Attorney General John Ashcroft to issue a decision in 2002 holding that any drug trafficking crime is presumptively a particularly serious crime. ${ }^{130}$ The opinion reversed three separate BIA decisions that had held that drug trafficking convictions were not particularly serious crimes. ${ }^{131}$ In so doing, the Attorney General's opinion was highly critical of the BIA's case-by-case approach, noting that the BIA's application of "an individualized, and often haphazard, assessment as to the 'seriousness' of an alien defendant's crime ... has led to results that are both inconsistent and, as plainly evident here, illogical." 132

The Attorney General attempted to address this problem by stressing the importance of the "harmful character of a crime" and minimizing the significance of factors such as the length of the sentence. ${ }^{133}$ Although the Attorney General noted that he "might be well within [his] discretion to conclude that all drug trafficking offenses are per se 'particularly serious crimes' under the INA," he found it unnecessary "to exclude entirely the possibility of very rare case where an alien may be able to demonstrate extraordinary and

${ }^{126}$ Id. at 360; see also In re N-A-M-, 24 I. \& N. Dec. 336, 344 (B.I.A. 2007) (explaining that the "nature of the crime" is "measured by its elements").

${ }^{127}$ In re U-M-, 20 I. \& N. Dec. 327, 330-31 (B.I.A. 1991) ("We find that the crime of trafficking in drugs is inherently a particularly serious crime ... no further inquiry is required into the nature and circumstances of the respondent's convictions for sale or transportation of marihuana and sale of LSD."); In re Gonzalez, 19 I. \& N. Dec. 682, 683-84 (B.I.A. 1988) (indicating that drug trafficking is a particularly serious crime); In re Garcia-Garrocho, 19 I. $\&$ N. Dec. 423, 426 (B.I.A. 1986) (holding that a conviction for first-degree burglary under a New York statute was "per se "particularly serious"" because it required "aggravating circumstances" that "involve[d] physical injury or potentially life-threatening acts").

12821 I. \& N. Dec. 639 (B.I.A. 1996)

${ }^{129} \mathrm{Id}$. at $650-51$ (holding that categorizing certain crimes as per se particularly serious, whether by statute or case law, did not violate the United States' international obligations under the Refugee Convention or the Protocol).

${ }^{130}$ In re Y-L-, 23 I. \& N. Dec. 270, 274 (Att'y Gen. 2002).

131 Id.

132 Id. at 273.

133 Id. at 273-74. 
compelling circumstances that justify treating a particular drug trafficking crime as falling short of that standard." 134 The decision set forth six specific criteria that provided a minimum standard for overcoming the presumption that a drug trafficking crime is particularly serious. ${ }^{135}$

In 2007, the BIA issued its decision in $N-A-M$-, which provided a more detailed explanation of its approach for determining whether or not a conviction is a particularly serious crime. ${ }^{136}$ This case addressed for the first time the interplay between the elements of an offense and the fact-specific analysis. The BIA explained:

If the elements of the offense do not potentially bring the crime into a category of particularly serious crimes, the individual facts and circumstances of the offense are of no consequence, and the alien would not be barred from a grant of withholding of removal. On the other hand, once the elements of the offense are examined and found to potentially bring the offense within the ambit of a particularly serious crime, all reliable information may be considered in making a particularly serious crime determination, including the conviction records and sentencing information, as well as other information outside the confines of a record of conviction. ${ }^{137}$

Here, the BIA instructed immigration judges to first look at the elements to determine if the crime is clearly outside the reach of the particularly serious crime bar. If the crime could potentially be particularly serious based on the elements, then the judge is allowed to look at individualized facts but is not required to do so. This approach presents two major challenges. First, it remains unclear what elements bring an offense "within the ambit" of a particularly serious crime. This makes it extremely difficult to apply the initial step of the analysis and leads to arbitrary and inconsistent decisions. Second, adjudicators "may"- but are not required to - consider all reliable information, which also results in ad hoc decisions about whether to employ an element-based or factbased approach. Each of these issues is discussed below.

$134 I d$ at 276.
$135 I d$ at $276-77$. These six criteria are:

“(1) a very small quantity of controlled substance; (2) a very modest amount of money paid for the drugs in the offending transaction; (3) merely peripheral involvement by the alien in the criminal activity, transaction, or conspiracy; (4) the absence of any violence or threat of violence, implicit or otherwise, associated with the offense; (5) the absence of any organized crime or terrorist organization involvement, direct or indirect, in relation to the offending activity; and (6) the absence of any adverse or harmful effect of the activity or transaction on juveniles."

Id.

${ }^{136}$ In re N-A-M-, 24 I. \& N. Dec. 336, 342 (B.I.A. 2007).

137 Id 


\section{The Unidentified Elements of a Particularly Serious Crime}

The first challenge with the BIA's test in $N-A-M$ - is that the BIA has never identified the elements of a particularly serious crime. The BIA has indicated that crimes against persons, especially crimes involving the use of force, violence, or threats, are "more likely" to be particularly serious crimes. ${ }^{138}$ This rule of thumb also appears to include crimes against animals, because the BIA has found that harming a poodle constitutes a particularly serious crime. ${ }^{139}$ However, the BIA has never limited particularly serious crimes to such offenses. In fact, the BIA has explicitly stated that an offense "does not have to be violent to be a particularly serious crime," 140 and it has cautioned, "there may be instances where crimes (or a crime) against property will be considered [particularly serious]."141 Thus, the BIA has not made the use of force or harm to a living being a necessary element of a particularly serious crime.

Similarly, while the BIA has indicated that evil intent is relevant to the particularly serious crime determination, it has never held that this is a required element. ${ }^{142}$ Cases indicating the relevance of intent include In re $L-S-,{ }^{143}$ where the BIA reasoned that because a conviction for alien smuggling could be motivated by love, charity, kindness, or religious principles, adjudicators should "exercise great caution in designating such an offense as a particularly serious crime for purposes of [withholding of removal]."144 Furthermore, in an unpublished decision, the BIA decided that telephoning a bomb threat was a particularly serious crime because the statute included a "willful" and "malicious" intent requirement. ${ }^{145}$ Similarly, Madrid v. Holder ${ }^{146}$ stressed that the elements of the crime required malicious and intentional harm. ${ }^{147}$ But, the BIA has also found crimes requiring only recklessness or negligence to be particularly serious. For example, the BIA has found that convictions for

${ }_{138}$ See In re S-V-, 22 I. \& N. Dec. 1306, 1309 (B.I.A. 2000) (finding a conviction for armed robbery to be a "particularly serious crime"); In re Frentescu, 18 I. \& N. Dec. 244, 247 (B.I.A. 1982) (finding that "[c]rimes against persons are more likely to be categorized as "particularly serious crimes").

139 See Madrid v. Holder, 541 F. App'x 789, 791 (9th Cir. 2013) (involving a violation of a California law that prohibits malicious and intentional harming of animals).

140 In re R-A-M-, 25 I. \& N. Dec. 657, 662 (B.I.A. 2012).

141 Frentescu, 18 I. \& N. Dec. at 247.

142 In re G-G-S-, 26 I. \& N. Dec. 339, 346-47 (B.I.A. 2014).

14322 I. \& N. Dec. 645 (B.I.A. 1999).

144 Id. at 655 (citing In re Tiwari, 19 I. \& N. Dec. 875 (B.I.A. 1989)).

145 See Abpikar v. Holder, 544 F. App'x 719, 723 (9th Cir. 2013) (citing Blandino-Medina v. Holder, 712 F.3d 1338, 1346-47 (9th Cir. 2013) (vacating the BIA's decision that a conviction for telephoning a bomb threat was per se particularly serious based on a precedent holding that the BIA cannot classify crimes as per se particularly serious for purposes of withholding of removal).

146541 F. App'x 789 (9th Cir. 2013).

147 Id. at 791-92. 
reckless endangerment (shooting a gun into the air illegally), reckless homicide, and driving under the influence are particularly serious crimes. ${ }^{148}$ In the Matter of $G-G-S-1,{ }^{149}$ the BIA explained, "since the focus in a particularly serious crime analysis is whether the offense justifies a determination that the respondent 'is a danger to the community,' an inquiry regarding evil intent or fraud is not necessarily dispositive." 150

In practice, such a wide range of offenses have been classified as particularly serious crimes that it is difficult to identify which elements indicate that the crime in question does or does not come "within the ambit" of this classification. In terms of crimes against property, even financial crimes have been deemed particularly serious. In Kaplun v. Attorney General of the United States, ${ }^{151}$ the petitioner argued that the BIA had erred in finding that his conviction for securities fraud, an aggravated felony with a sentence of less than five years, was a particularly serious crime. ${ }^{152} \mathrm{He}$ pointed out that no BIA precedents had held that a nonviolent, white-collar offense could constitute a particularly serious crime. ${ }^{153}$ The Third Circuit rejected this argument, reasoning that the INA makes all aggravated felonies with a sentence of at least five years particularly serious crimes, and aggravated felonies include a number of nonviolent financial crimes. ${ }^{154}$ The court noted, "nothing in our precedent suggests that a financial crime cannot, as a matter of law, be a particularly serious crime." 155

Other courts have also upheld BIA determinations that financial crimes constitute particularly serious crimes. The Ninth Circuit, for example, upheld a BIA decision that a conviction for mail fraud, resulting in a $\$ 650,000$ restitution order and a sixteen-month sentence, was a particularly serious crime. ${ }^{156}$ Similarly, the Fifth Circuit upheld a BIA determination that a conviction for money laundering, resulting in a sentence of thirty-seven months, constituted a

148 Saqr v. Holder, 580 F.3d 414, 418 (6th Cir. 2009) (finding that the BIA affirmed the immigration judge's determination that reckless homicide is a particularly serious crime); Delgado v. Holder, 563 F.3d 863, 865 (9th Cir. 2009) (stating that the BIA found that three prior offenses of driving under the influence constituted "particularly serious crimes"); Nethagani v. Mukasey, 532 F.3d 150, 152, 155 (2d Cir. 2008) (upholding the BIA's determination that first-degree reckless endangerment is a particularly serious crime).

14926 I. \& N. Dec. 339 (B.I.A. 2014).

${ }^{150} \mathrm{Id}$. at 347 (holding that the respondent's conviction for assault with a deadly weapon, a general intent crime under California law, was a particularly serious crime and that the role of respondent's mental illness was irrelevant to the analysis because it had not been raised in criminal court).

151602 F.3d 260 (3d Cir. 2010).

152 Id. at 267-68.

153 Id.

154 Id.

${ }_{155}$ Id. at 268.

156 Arbid v. Holder, 700 F.3d 379, 385 (9th Cir. 2012) (holding the BIA did not abuse its discretion in finding a scheme to defraud victims to be a particularly serious crime). 
particularly serious crime. ${ }^{157}$ In that case, the BIA reasoned that money laundering presented a danger to the community because it was related to drug trafficking. ${ }^{158}$ In another case involving identity theft and access device fraud, the Fifth Circuit affirmed that the crimes were particularly serious because the petitioner was "involved in a large scale scheme that resulted in losses to 23 different individuals and banking organizations, the theft of 419 identities, and a loss of $\$ 54,329.44 . " 159$

There are also cases indicating that the BIA has deemed "crime[s] against the orderly pursuit of justice" to be particularly serious. ${ }^{160}$ For instance, in one case, the BIA found that resisting arrest was a particularly serious crime. There, the respondent had "[run] through traffic to evade arrest, assumed a 'fighting stance' with the police officer, and shoved [the officer] when he tried to place [the respondent] under arrest."'161 The Ninth Circuit vacated the BIA's decision, stating "we cannot discern ... the operative rationale of its particularly serious crime determination." 162 In another case, the BIA found that a conviction for tampering with evidence constituted a particularly serious crime. In that case, the BIA stressed that the underlying facts, which involved hacking up a corpse, demonstrated "gruesome brutality." 163

Even some victimless crimes have been classified as particularly serious. One appellate case characterized a BIA finding that prostitution is a particularly serious crime as being based not any particular evidence, but rather on "the totality of the impact prostitution inflicts upon a community."164 The Court of

157 Hakim v. Holder, 628 F.3d 151, 154-55 (5th Cir. 2010) (finding the BIA applied the correct legal standard in determining that a money laundering scheme was a particularly serious crime).

${ }^{158} \mathrm{Id}$. at 152 .

159 Yang v. Holder, 570 F. App'x 381, 385 (5th Cir. 2014) (rejecting the petitioner's argument that his counsel had been ineffective in conceding to the particularly serious crime determination).

160 See Alphonsus v. Holder, 705 F.3d 1031, 1036 (9th Cir. 2013).

161 Id. at 1047.

162 Id. at 1044.

${ }^{163}$ Denis v. Att'y Gen. of the United States, 633 F.3d 201, 216 (3d Cir. 2011). The petitioner was convicted under Section 215.40 of the New York Penal Laws, which provides:

A person is guilty of tampering with physical evidence when:

1. With intent that it be used or introduced in an official proceeding or a prospective official proceeding, he (a) knowingly makes, devises or prepares false physical evidence, or (b) produces or offers such evidence at such a proceeding knowing it to be false; or

2. Believing that certain physical evidence is about to be produced or used in an official proceeding or a prospective official proceeding, and intending to prevent such production or use, he suppresses it by any act of concealment, alteration or destruction, or by employing force, intimidation or deception against any person.

Tampering with physical evidence is a class $\mathrm{E}$ felony.

N.Y. PENAL LAW $\S 215.40$ (McKinney 2010).

164 Yuan v. U.S. Att'y Gen., 487 F. App'x 511, 514 (11th Cir. 2012) (quoting the BIA's 
Appeals for the Eleventh Circuit vacated this decision because "[t]he BIA reached this conclusion without examining the elements of the offense, the circumstances of the conviction, or the type of sentence imposed," as required by Frentescu. ${ }^{165}$ The court remanded to the BIA without reaching the issue of whether a single conviction for prostitution (or, for that matter, multiple convictions) constitutes a particularly serious crime. ${ }^{166}$ However, the Eleventh Circuit did note that "the BIA's reasoning reflect[ed] no analytical framework by which it can rationally distinguish crimes that are 'particularly serious' from those that are not," because "every petty crime, such as speeding, jaywalking, and loitering, has an impact on the community." 167 Unless the BIA identifies with greater specificity what elements do or do not bring an offense within the ambit of a particularly serious crime, this critique remains relevant today.

These decisions demonstrate that a wide range of crimes, violent and nonviolent, against people and against property, with and without evil intent, can be considered "particularly serious." Given the expansive interpretation of this term, it remains unclear what elements bring an offense "within the ambit" of a particularly serious crime. Likewise, it remains unclear what elements remove an offense from the ambit of this classification. Consequently, immigration judges tend to almost always look at the underlying facts and circumstances before making a determination. For example, in Arbid, where the Ninth Circuit examined the immigration judge's decision that a conviction for mail fraud was a particularly serious crime, the court noted that " $t]$ he [immigration judge] began his analysis with a review of the Frentescu factors." 168 This suggests that the immigration judge did not first decide whether the elements brought the offense within the ambit of a particularly serious crime as required by $N-A-M-$.

The Third Circuit case involving tampering with evidence similarly raises questions about why the elements brought the offense within the ambit of a particularly serious crime. In that case, the facts regarding dismembering a corpse were terrible, but it is unclear why the elements alone would signal the possibility of a particularly serious crime. ${ }^{169}$ There, the petitioner made the argument that the elements did not bring the offense within the ambit of a particularly serious crime because the conduct did not involve the use of force or violence against another person; the court rejected this argument, however, stating simply that other offenses can also be viewed as particularly serious crimes. ${ }^{170}$ This reasoning suggests that there are no clear boundaries for "safe harbor" pleas that fall outside the ambit of a particularly serious crime. The BIA asserts that the elements of a crime are the "essential key" to the analysis, but it

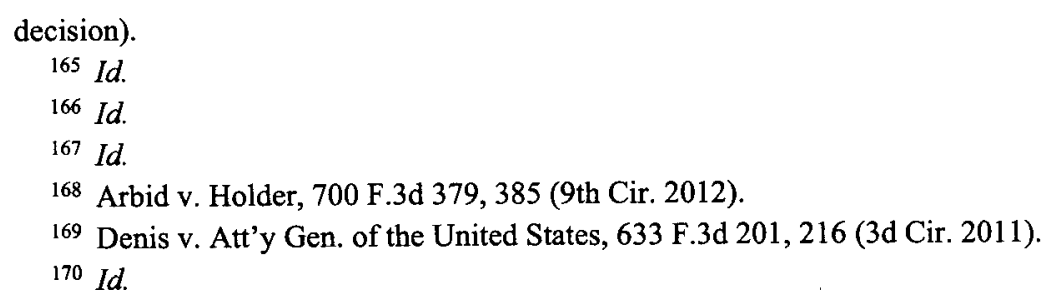


has provided no concrete guidance about what elements do or do not fall within the ambit of a particularly serious crime.

\section{Ad Hoc Decisions About Whether to Use an Element-Based or Fact- Based Approach}

Because $N-A-M$ - simply states that all reliable information may be considered once the offense is within the ambit of a particularly serious crime, adjudicators are not required to look beyond the elements of an offense. ${ }^{171}$ In fact, in that very case, the BIA concluded that the respondent's conviction was "a particularly serious crime based solely on its elements."172 The Colorado statute under which the respondent had been convicted required a person to use, or represent that he or she was armed with, a deadly weapon, and to knowingly place or attempt to place another person in fear of imminent serious bodily injury. ${ }^{173}$ The BIA reasoned that because this statutory provision required a serious threat to others, the offense was a crime against a person, and because "crimes against persons are more likely to be categorized as particularly serious ... the respondent was convicted of a particularly serious crime."174 The BIA did not explain the logical leap from being "more likely" to be particularly serious to being per se particularly serious. As mentioned above, there are several other cases where the BIA has held that certain convictions are particularly serious on their face. ${ }^{175}$

Several courts of appeals have upheld BIA determinations that a crime is particularly serious on its face. The Sixth Circuit, for example, affirmed the BIA's determination that assault with a firearm with intent to murder is inherently a particularly serious crime. ${ }^{176}$ The court also affirmed the BIA's conclusion that a noncitizen convicted of felonious assault, possession of a firearm in the commission of a felony, and carrying a pistol in a vehicle, had been convicted of a particularly serious crime because the elements indicated that the conduct involved "the substantial risk of violence towards another person." 177 The Second Circuit found that first-degree manslaughter is per se a

171 See supra notes 136-37 and accompanying text. Prior decisions also indicate that an adjudicator need not go beyond the elements of an offense in determining that it constitutes a particularly serious crime. See, e.g., Hamama v. INS, 78 F.3d 233, 240 (6th Cir. 1996) (noting that the Board may find some crimes to be per se particularly serious without needing to examine the individual circumstances of the crime); In re Garcia-Garrocho, 19 I. \& N. Dec. 423,426 (B.I.A. 1986) (looking at the elements of the offense of burglary in the first degree and finding that, on its face, such a crime is a particularly serious one).

${ }^{172}$ In re N-A-M-, 24 I. \& N. Dec. 336, 343 (B.I.A. 2007).

${ }^{173}$ Id. (discussing CoLo. REV. STAT. §§ 18-3-206(1)(a)-(b) (2006)).

174 Id.

175 See, e.g., Garcia-Garrocho, 19 I. \& N. Dec. at 425-26; In re Carballe, 19 I. \& N. Dec. 357, 360-61 (B.I.A. 1986).

${ }^{176}$ Gjonaj v. INS, 47 F.3d 824, 826 (6th Cir. 1995).

${ }^{177}$ Hamama v. INS, 78 F.3d 233, 240 (6th Cir. 1996). 
particularly serious crime, even though the petitioner in that case testified that she shot her abusive husband in self-defense. ${ }^{178}$ Furthermore, the Eleventh Circuit has stated that immigration judges are "free to rely solely on the elements of the offense" in making a particularly serious crime determination. ${ }^{179}$

So far, only the Ninth Circuit has held that it is impermissible for an adjudicator to classify a crime as per se particularly serious. In Blandino-Medina $v$. Holder, ${ }^{180}$ the Ninth Circuit found that the BIA erred in finding that the felony of lewd and lascivious conduct with a child under the age of fourteen in violation of California Penal Code 288(a) was per se a particularly serious crime. ${ }^{181}$ The court reasoned that the overall structure of the INA compels the conclusion that Congress created only one category of per se particularly serious crimes for withholding of removal (aggravated felonies with a sentence of at least five years), requiring the BIA to conduct a case-by-case analysis for all convictions outside that category. ${ }^{182}$ The court also noted that, while the asylum statute allows the Attorney General to designate by regulation which offenses are considered particularly serious crimes, there is no analogue in the withholding of removal statue. ${ }^{183}$ The Third Circuit has also used language that calls into questions whether it is legally permissible to classify offenses as per se particularly serious. ${ }^{184}$

Allowing adjudicators to declare certain crimes per se particularly serious leaves immigration judges free to make ad hoc decisions about whether to apply an element-based or fact-based approach. This leads to arbitrary, inconsistent, and unpredictable outcomes. Furthermore, deciding that a crime is per se particularly serious is different than applying the categorical approach. In cases following the BIA's lead that certain crimes are per se particularly serious crimes, adjudicators do not compare the elements of the statute of conviction to the generic federal offense. Consequently, a crime such as burglary that is defined differently in different states and does not always meet the federal generic definition of burglary could be deemed a particularly serious crime even in states where a critical element such as unlawful entry is missing. ${ }^{185}$

${ }_{178}$ Ahmetovic v. INS, 62 F.3d 48, 52 (2d Cir. 1995); see also Hamama, 78 F.3d at 240 (holding that "some crimes are facially "particularly serious" and that the BLA "has the prerogative to declare a crime particularly serious without examining each and every Frentescu factor").

179 Lapaix v. U.S. Att'y Gen., 605 F.3d 1138, 1143 (11th Cir. 2010).

180 Blandino-Medina v. Holder, 712 F.3d 1338 (9th Cir. 2013).

${ }^{181}$ Id. at 1343-47 (concluding that Congress has precluded the agency from creating new categories of per se particularly serious crimes).

$182 \mathrm{Id}$. at 1345.

183 Id. at 1346.

${ }^{184}$ See Chong v. INS, 264 F.3d 378, 388 (3d Cir. 2001).

${ }_{185}$ See supra Section I.A (discussing the consequences of disconnecting a state statute's elements of conviction from the generic federal offense in other contexts). 
One alternative to this ad hoc approach is to apply the categorical approach to the particularly serious crime bar just as it is applied to other convictions that are bars to various forms of relief. ${ }^{186}$ For this to work, of course, the BIA must identify the elements that are required for a conviction to be a particularly serious crime, as discussed above, ${ }^{187}$ or limit particularly serious crimes to aggravated felonies (for asylum) or aggravated felonies with a sentence of at least five years (for withholding of removal). ${ }^{188}$ Another alternative is to require a completely individualized analysis. The following Part explores this second option, which is how UNHCR interprets the particularly serious crime bar.

\section{THE INDIVIDUALIZED APPROACH}

Just as the BIA's test for determining whether a conviction should be classified as a particularly serious crime does not use the categorical approach, nor does it apply a fully individualized analysis. The BIA departs from an individualized approach not only by allowing some crimes to be deemed per se particularly serious, but also by excluding certain factual considerations from the analysis. ${ }^{189}$ Because UNHCR interprets the particularly serious crime bar in the Refugee Convention as requiring an individualized approach, this Part begins by discussing the historical origin of the bar. After explaining UNHCR's interpretation and its underlying concerns regarding consistency and fairness, this Part shows how the BIA's current test departs from UNHCR's approach.

\section{A. Historical Origins}

The particularly serious crime bar in U.S. asylum law comes from Article 33 of the Refugee Convention. The first part of Article 33 sets forth the nonrefoulement principle, stating that "[n]o Contracting State shall expel or return ('refouler') a refugee in any manner whatsoever to the frontiers of territories where his life or freedom would be threatened on account of his race, religion, nationality, membership of a particular social group or political opinion."190 Initial drafts of the Refugee Convention did not include any exceptions to this fundamental principle of nonrefoulement. ${ }^{191}$ The U.K. representative on the committee responsible for drafting the Refugee Convention expressed concerns about "how to deal with cases where a refugee was disturbing the public order of the UK," referring "not to ordinary crimes,

186 See infra Section III.A (discussing how a categorical approach to determining particularly serious crimes would be applied in practice).

187 See supra notes 171-79 and accompanying text (discussing an element-based approach to determining particularly serious crimes).

188 See supra note 60 and accompanying text.

189 See infra Section II.C (discussing how the BIA fails to incorporate important factors and legal principles into its nonrefoulment assessments).

190 Refugee Convention, supra note 2, art. 33(1).

191 GuY S. GoOdWIN-Gill \& JANE MCAdam, The RefugeE in InTERNATIONAL LaW 20304 (3d ed. 2007). 
but to such acts as inviting disorder."192 The U.S. representative thought "it would be highly undesirable to suggest in the text of that Article that there might be cases, even highly exceptional cases, where a man might be sent to death or persecution." 193 The French representative agreed with the U.S. position, considering it "absolutely inhuman" and "contrary to the very purpose of the Convention" to return a genuine refugee to his country of origin, even in exceptional circumstances. ${ }^{194}$

But, by the time the Conference of the Plenipotentiaries took place, the international situation had deteriorated, and two proposals were offered for an exception to the nonrefoulement principle. Sweden proposed an exception "in cases where the presence of a refugee in the territory of a Contracting State would constitute a danger to national security or public order." 195 This exception was intended to apply in situations where "refugees engaged in subversive activities threatening the security of their country of asylum."196

France and the United Kingdom proposed different language, stating that the benefit of nonrefoulement "may not, however, be claimed by a refugee whom there are reasonable grounds for regarding as a danger to the security of the country in which he is residing, or who, having been lawfully convicted in that country of particularly serious crimes of [sic] offences, constitutes a danger to the community thereof." 197 France and the United Kingdom stressed that their key concern was protecting national security. ${ }^{198}$ They were worried that some refugees would be "tempted to engage in activities on behalf of a foreign Power against the country of their asylum" and thought it would be unreasonable not to allow a state to protect itself. ${ }^{199}$ The U.K. representative indicated that a state should be able "to decide whether the danger entailed to refugees by expulsion outweighed the menace to public security if they were permitted to stay." 200

During the discussion, the word "offences" was dropped from the English version of the proposal and the words "by final judgment" were added.201 A suggestion to change the phrase to "particularly serious acts" was rejected as subject to arbitrary interpretations. ${ }^{202}$ Likewise, a suggestion to add language

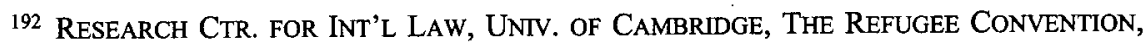
1951: THE TravauX PREPARATOIRES ANALYSED 326 (Paul Weis ed., 1995).

$193 \mathrm{Id}$.

194 Id. at 327.

${ }^{195}$ Id. at 328 (emphasis omitted).

$196 \mathrm{Id}$. at 330.

197 Id. at 328.

198 Id. at 329-30.

${ }^{199}$ Id. at 330.

$200 \mathrm{Id}$. at 329.

201 Id. at $332,335$.

${ }^{202} \mathrm{Id}$. at 333 (emphasis added) ("The French representative suggested that,in [sic] order to simplify matters, 'convicted because of particularly serious acts' could be substituted. The Belgian representative could not accept those words, which he thought could be interpreted 
extending the exception to those "declared by a court an habitual offender" was rejected as unduly widening the exception. ${ }^{203}$ The U.K. representative noted that a habitual offender could include someone with an accumulation of petty crimes, which was outside the scope of the provision. ${ }^{204}$

Ultimately, an amended version of the exception proposed by France and the United Kingdom was adopted. The final version of the language contained in Article 33(2) reads:

The benefit of the present provision may not, however, be claimed by a refugee whom there are reasonable grounds for regarding as a danger to the security of the country in which he is, or who, having been convicted by $a$ final judgment of a particularly serious crime, constitutes a danger to the community of that country. 205

In 1968, the United States ratified the Protocol Relating to the Status of Refugees, which incorporates Articles 2 through 34 of the Refugee Convention. ${ }^{206}$ The United States codified these international obligations in the Refugee Act of 1980, which is now part of the INA.207

Both parts of the exception in Article 33(2) appear, in almost identical language, in the INA. The first part provides an exception to withholding of removal if "there are reasonable grounds to believe that the alien is a danger to the security of the United States." 208 The second part applies if "the alien, having been convicted by a final judgment of a particularly serious crime is a danger to the community of the United States." 209 Although the INA preserves the language of Article 33(2), by breaking up the exception into two different statutory provisions, it loses sight of the relationship between particularly serious crimes and concerns about threats to national security, thereby opening the door to a broader interpretation of a "particularly serious crime" than the drafters of the Refugee Convention intended.

The commentary on the Travaux Preparatoires provided by Paul Weis confirms that Article 33(2) should be interpreted narrowly. He remarked, for example, "Not every reason of national security may be invoked, the refugee must constitute a danger to the national security of the country." ${ }^{210}$ Furthermore, while Weis recognized that "[w] hat crimes are meant is difficult to define," he set a high standard, noting that "capital crimes such as murder, rape, armed

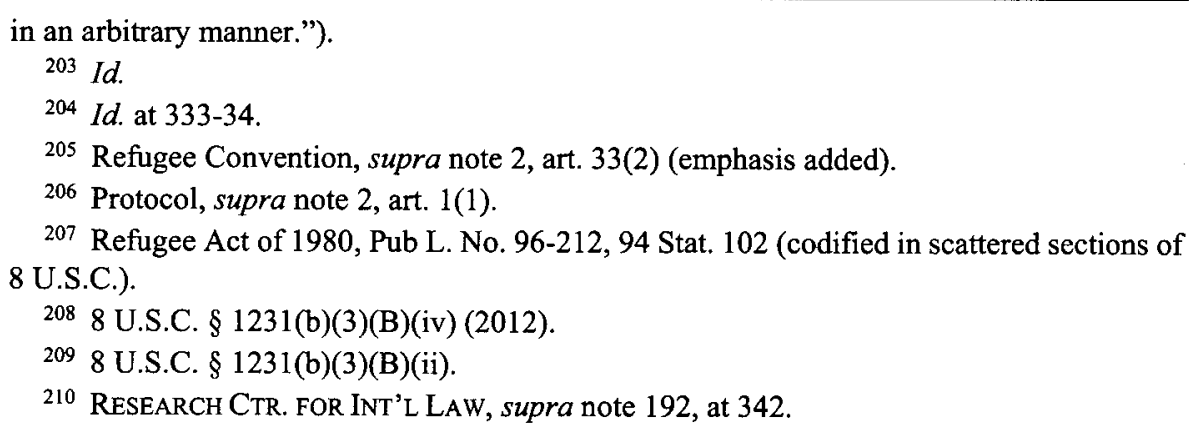


robbery and arson are included."211 Another important aspect of Weis's commentary is his view that Article 33(2) requires that "[t]wo conditions must be fulfilled: the refugee must have ben [sic] convicted by final judgment for a particularly serious crime, and he must constitute a danger to the community of the country." 212 Underscoring the distinct nature of these requirements, Weis noted, "a particularly serious crime, if committed in a moment of passion, may not necessarily constitute the refugee as a danger to the community." 213 Finally, Weis's commentary echoed the perspective of the U.K. representative by stating that "[t]he principle of proportionality has to be observed." 214 In other words, the seriousness of the crime must be balanced against the risk of persecution if the person is sent home. UNHCR has embraced this interpretation.

\section{B. UNHCR's Interpretation}

UNHCR has stressed that the particularly serious crime bar "applies to refugees who become an extremely serious threat to the country of asylum due to the severity of crimes perpetrated by them." 215 In interpreting what constitutes a particularly serious crime, UNHCR has shown concern for consistency, stating that "the gravity of the crimes should be judged against international standards, not simply by its categorisation in the host State or the nature of the penalty." 216 According to UNHCR, "[c]rimes such as petty theft or the possession for personal use of illicit narcotic substances [do] not meet the threshold of seriousness," while "murder, rape, arson, and armed robbery" are examples of crimes that do. ${ }^{217}$ UNHCR mentions various factors to be considered in evaluating the seriousness of a crime, "includ[ing] the nature of the act, the actual harm inflicted, the form of procedure used to prosecute the crime, and whether most jurisdictions would consider the act in question as a serious crime." 218 The last two factors underscore UNHCR's concern about consistency. UNHCR notes that "[i]f it is generally understood that a 'serious crime' is a capital or a very grave crime normally punished with long imprisonment, it follows that a 'particularly serious crime', must belong to the gravest category." 219

\footnotetext{
211 Id.

$212 \mathrm{Id}$

$213 \mathrm{Id}$.

214 Id.

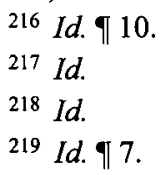

${ }^{215}$ U.N. High Comm'r for Refugees (UNHCR), Criminal Justice and Immigration Bill: Briefing for the House of Commons at Second Reading, I 7 (July 2007), http://www.unhcr.org/en-us/576d237f7.pdf [https://perma.cc/XPL9-DUYU] (emphasis added). 
Furthermore, UNHCR has taken the position that "[c]onviction of a particularly serious crime in and of itself is not sufficient. ${ }^{.220}$ The person must also be a danger to the community, which requires "an assessment of the present or future danger posed by the wrong-doer." 221 UNHCR believes that the State should bear the burden of showing that the person's conviction(s) "are symptomatic of the criminal, incorrigible nature of the person and that he is likely to do it again." 222 This view differs from the operation of immigration law in the United States, where the respondent bears the burden of establishing eligibility for all forms of relief from removal. In order to assess present and future danger, UNHCR notes that the State should examine "the circumstances of the refugee as well as the particulars of the specific offence." 223 Relevant considerations include prospects for reform, rehabilitation, and integration into society: "Where the refugee has responded to rehabilitative measures, or where there are indications that the refugee can be reformed, Article 33(2) should not apply because the potential threat to the community would have been (or could be) removed."224

In evaluating the seriousness of a crime, UNHCR finds it critical to consider "the overall context of the offence, including its nature, effects and surrounding circumstances, the offender's motives and state of mind, and the existence of extenuating (or aggravating circumstances)." 225 The reason that UNHCR wants "all available and relevant facts [to be] carefully and comprehensively assessed" is to ensure that the particularly serious crime determination comports with "the highest possible standards of fairness in decision-making."226 To further ensure fairness, UNHCR stresses that adjudicators should "carefully balance[]" competing considerations "relating to complicity, culpability, and mitigating or aggravating circumstances" and ensure "that applicants are given a full opportunity to present their claims." 227

Finally, according to UNHCR, a State must consider whether refoulement is "a proportional response to [the] danger" posed to the security of the community. ${ }^{228}$ UNHCR explains that "the proportionality [test] is necessary in order to ensure that the exception is applied in [a] manner consistent with the overriding humanitarian object and purpose of the 1951 Convention. ${ }^{.229}$

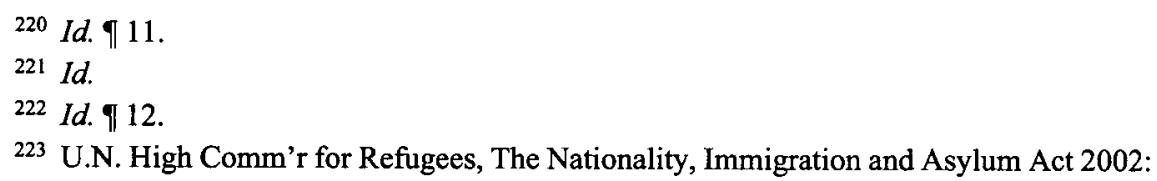
UNHCR Comments on the Nationality, Immigration and Asylum Act 2002 (Specification of Particularly Serious Crimes) Order 2004 (Nov. 2004).
224 Id.
225 Id.
${ }^{226} \mathrm{Id}$.
227 Id.
228 Id.
${ }^{229} \mathrm{Id}$. 
UNHCR acknowledges that the concept of proportionality is not explicitly mentioned in the Refugee Convention but stresses that "it is a fundamental principle in international human rights [law] and international humanitarian law." 230 In applying the proportionality test, states should bear in mind that the particularly serious crime bar is "a measure of last resort" that goes well beyond criminal sanctions and is justified by an "exceptional threat" that "can only be countered by removing the person from the country of asylum."231 Thus, UNHCR perceives the principle of proportionality as another way to promote both consistency and fairness.

\section{The BIA's Deviation from UNHCR's Approach}

Although Congress codified the obligations in Article 33 of the Refugee Convention using almost exactly the same language, the BIA's interpretation of the exception in Article 33(2) departs from UNHCR's interpretation in three significant ways. First, while UNHCR stresses that all relevant factors must be considered, including any mitigating circumstances, the BIA has excluded certain relevant factors from consideration. Second, while UNHCR has found that there must be a separate assessment of present or future dangerousness, the BIA has rejected any such assessment. ${ }^{232}$ Third, the BIA has refused to apply the principle of proportionality that UNHCR endorses.

\section{Failing to Consider All Mitigating Factors}

Beyond the per se classifications discussed above, the BIA has specifically excluded certain individualized - and potentially mitigating - factors from the particularly serious crime analysis. In $N-A-M-$, the BIA indicated that "offender characteristics" are not important because they "may operate to reduce a sentence but do not diminish the gravity of a crime." 233 In the Matter of $R-A-M-$ ,234 the BIA found that "potential rehabilitation is not significant to the analysis." 235 Most recently, in $G-G-S$-, the BIA discussed a specific offender characteristic that immigration judges cannot consider independently of the

$230 \mathrm{Id}$.

231 Id.; see also U.N. HIGH COMM'R FOR REFUgEeS, HANDBOOK ON PROCEDURES AND CRITERIA FOR DETERMINING REFUGEE STATUS UNDER THE 1951 CONVENTION AND THE 1967 Protocol Relating to the Status of Refugees, ๆ 155, U.N. Doc. HCR/IP/Eng/REV. 1, (1979, rev. 1992) (explaining that the principle of proportionality should be applied to the serious nonpolitical crime bar).

232 See generally David Delgado, Note, Running Afoul of the Non-Refoulement Principle: The [Mis] interpretation and [Mis]application of the Particularly Serious Crime Exception, 86 S. CAL. L. REV. POSTSCRIPT 1 (2013) (arguing that the BIA's interpretation that the particularly serious crime bar does not require a separate determination of dangerousness is contrary to the plain meaning of the statute as well as international consensus).

233 In re N-A-M-, 24 I. \& N. Dec. 336, 343 (B.I.A. 2007).

23425 I. \& N. Dec. 657 (B.I.A. 2012).

${ }^{235} I d$. at 662. 
criminal court: mental health status at the time of the offense. ${ }^{236}$ Reasoning that fact finders in criminal proceedings "have expertise in the applicable State and Federal criminal law, are informed by the evidence presented by the defendant and the prosecution, and have the benefit of weighing all the factors firsthand," the BIA concluded that immigration judges are constrained by how mental health issues were handled by the criminal court. ${ }^{237}$

In excluding specific individualized factors, the BIA contradicts its own precedents providing that "all reliable information may be considered in making a particularly serious crime determination." 238 The BIA justifies excluding facts such as mental illness by reasoning that immigration judges "cannot go behind the decisions of the criminal judge and reassess any ruling on criminal culpability. ${ }^{" 239}$ But taking into account offender characteristics such as mental illness, like considering other underlying facts and circumstances surrounding a crime, is different from assessing criminal culpability. The immigration judge is not retrying the question of guilt but assessing whether the crime is so serious as to justify removal to a country where there is a significant risk of persecution. ${ }^{240}$

Indeed, the BIA's concerns in $G-G-S$ - about "going behind" a conviction are in tension with at least one BIA decision pointing out that inquiries into the factual circumstances surrounding a crime "are by no means unusual in removal proceedings." ${ }^{241}$ Not only has the BIA recognized that "Immigration Judges are often called upon to examine the facts underlying a conviction to determine whether the alien is ineligible for asylum and withholding of removal as one convicted of a "particularly serious crime," 'but it has noted that they routinely do this in other contexts as well. ${ }^{242}$ For example, certain removability determinations require the immigration judge to engage in fact-finding about whether the alien's conduct creates "reason to believe" that the alien has been an illicit trafficker in a controlled substance, a human trafficker, or a money launderer. ${ }^{243}$ Other removability grounds require the immigration judge to determine if a fraud offense resulted in loss to the victim of more than $\$ 10,000 ; 244$ if an offense is one "relating to a controlled substance";245 if a

\footnotetext{
${ }^{236}$ In re G-G-S-, 26 I. \& N. Dec. 339, 339, 345 (B.I.A. 2014).

${ }^{237}$ Id. at 345.

${ }^{238} N-A-M-, 24$ I. \& N. Dec. at 338 (emphasis added).

239 G-G-S-, 26 I. \& N. Dec. at 345.

${ }^{240} C$ f. In re L-S-, 22 I. \& N. Dec. 645, 651 (B.I.A. 1999) ("[W]e do not engage in a retrial of the alien's criminal case or go behind the record of conviction to redetermine the alien's innocence or guilt.").

${ }^{241}$ In re Dominguez-Rodriguez, 26 I. \& N. Dec. 408, 413 (B.I.A. 2014).

242 Id. at 413 n.9.

243 See 8 U.S.C. $\S \S 1182(\mathrm{a})(2)(\mathrm{C}),(\mathrm{H})-(\mathrm{I})(2012)$.

${ }^{244}$ Nijhawan v. Holder, 557 U.S. 29, 38-40 (2009) (discussing 8 U.S.C. $\S 1101(\mathrm{a})(43)(\mathrm{M})(\mathrm{i}))$.

${ }^{245}$ Rojas v. Att'y Gen. of the United States, 728 F.3d 203, 215-16 (3d Cir. 2013) (en banc) (discussing 8 U.S.C. § 1227(a)(2)(B)(i)).
} 
conviction actually involved possession of marijuana for personal use; 246 or if the victim of a crime of violence had a qualifying "domestic" relationship to the offender. ${ }^{247}$ In none of these situations has the BIA expressed concerns that the immigration judge is "going behind the conviction" or engaging in a "mini-trial" of a criminal issue. ${ }^{248}$

In addition, certain discretionary waivers require an immigration judge to examine the circumstances relating to a crime. For example, in evaluating an application for a waiver of a criminal ground of inadmissibility under Section 212(h) of the INA, an immigration judge must determine if the noncitizen engaged in a "violent or dangerous crime[]," which would trigger a higher standard, requiring the noncitizen to demonstrate either "extraordinary circumstances" or "exceptional and extremely unusual hardship." 249 If extraordinary circumstances exist, the immigration judge must still assess the "gravity" of the offense to determine if a favorable exercise of discretion is warranted. 250

Similarly, in deciding whether to grant a discretionary waiver under former Section 212(c) of the INA, an immigration judge must examine the gravity of the offense in order to determine if it requires showing "unusual or outstanding equities." "251 The BIA has never precluded immigration judges from considering specific factors, such as mental health status, in assessing the seriousness of crimes for purposes of these waivers. Nor has the BIA excluded such factors in assessing the gravity of a crime for purposes of the "serious nonpolitical crime" bar to asylum and withholding. By failing to provide a cogent explanation for why an immigration judge should not be allowed to consider certain relevant facts in the particularly serious crime determination, the BIA opens the door to arbitrarily excluding other types of facts from the analysis as well.

\section{Dropping Dangerousness}

A second way that the United States departs from UNHCR's interpretation of Article 33(2) is that it has dropped dangerousness as a distinct requirement. ${ }^{252}$ As noted above, Carballe held that "those aliens who have been finally

${ }^{246}$ Mellouli v. Holder, 719 F.3d 995, 1000-01 (8th Cir. 2013) (discussing 8 U.S.C. $\$ 1227$ (a)(2)(B)(i)); Dominguez-Rodriguez, 26 I. \& N. Dec. at 409-14 (same); In re Davey, 26 I. \& N. Dec. 37, 38-41 (B.I.A. 2012) (same).

${ }^{247}$ Bianco v. Holder, 624 F.3d 265, 270-73 (5th Cir. 2010) (discussing 8 U.S.C. $\S 1227(\mathrm{a})(2)(\mathrm{E})(\mathrm{i}))$.

248 See Dominguez-Rodriguez, 26 I. \& N. Dec. at 412-13 ("[T]he circumstance-specific inquiry contemplated by the 'possession for personal use' exception does not invite Immigration Judges to redetermine an alien's criminal guilt or innocence.").

2498 C.F.R. $\$ 1212.7$ (d) (2017).

$250 \mathrm{Id}$.

251 In re Marin, 16 I. \& N. Dec. 581, 585-86 (B.I.A. 1978); see also In re Edwards, 20 I. \& N. Dec. 191, 196 (B.I.A. 1990); In re Buscemi, 19 I. \& N. Dec. 628, 633 (B.I.A. 1988).

252 In re Carballe, 19 I. \& N. Dec. 357, 360 (B.I.A. 1986). 
convicted of particularly serious crimes are presumptively dangers to [the] ... community." 253 Despite using the word "presumptively," the BIA has not applied any type of rebuttable presumption of dangerousness based on a past conviction for a particularly serious crime. Evidence of rehabilitation would be highly relevant to rebutting this type of presumption, but, as mentioned above, the BIA has found such evidence irrelevant to the analysis. ${ }^{254}$ In eliminating any assessment of dangerousness, the BIA relied on a House Judiciary Committee Report that referred to "aliens... who have been convicted of particularly serious crimes which make them a danger to the community of the United States." 255 The BIA interprets this language as establishing a cause-and-effect relationship between the conviction and the danger, and federal appellate courts have given deference to that interpretation. ${ }^{256}$

The BIA's interpretation conflicts with a letter from Senator Edward Kennedy, then-Chairman of the Senate Subcommittee on Immigration and Refugee Affairs, stating that Congress intended the statute to require a separate finding of dangerousness to the community. ${ }^{257}$ However, because postenactment legislative history receives "less weight than contemporaneous commentary," the courts have found that any weight given to this letter is "counterbalanced by the prepassage legislative history." 258 While the Second Circuit stated that it was "troubled by the BIA's failure to give separate consideration to whether [the petitioner] is a "danger to the community," noting that under this interpretation "the clause concerning 'danger to the community' might seem superfluous," it still followed other courts and deferred to the BIA's interpretation. ${ }^{259}$ At least one judge on the Tenth Circuit has shared the Second Circuit's concern about rendering the statutory phrase meaningless. ${ }^{260}$

$253 I d$.

${ }^{254}$ In re R-A-M-, 25 I. \& N. Dec. 657, 662 (B.I.A. 2012).

255 Carballe, 19 I. \& N. Dec. at 359 (quoting H.R. REP. No. 96-608, at 17 (1979)).

256 See Al-Salehi v. INS, 47 F.3d 390, 394 (10th Cir. 1995); Martins v. INS, 972 F.2d 657 , 660-61 (5th Cir. 1992); Arauz v. Rivkind, 845 F.2d 271, 275 (11th Cir. 1988); RamirezRamos v. INS, 814 F.2d 1394, 1397 (9th Cir. 1987) ("A close reading of the language of the statute leads us to the conclusion that the BIA's interpretation is reasonable."); see also Ahmetovic v. INS, 62 F.3d 48, 53 (2d Cir. 1995).

257 Mosquera-Perez v. INS, 3 F.3d 553, 556 (1st Cir. 1993) (taking note of the letter to the INS from Senator Kennedy showing that Congress "contemplated that a showing of dangerousness to the community would be necessary in addition to proof of conviction of an aggravated felony"); see also Delgado, supra note 232, at 32 (noting that Senator Kennedy "specifically stated that Congress intended that the language of the statute require a separate finding of dangerousness to the community").

258 Al-Salehi, 47 F.3d at 395 (quoting Mosquera-Perez, 3 F.3d at 558); see also Martins, 972 F.2d at 661 (rejecting the notion put forth in the Kennedy letter based on contradictory indications of legislative intent in pre-passage legislative history).

259 Ahmetovic, 62 F.3d at 52-53 ("[T]he BIA's interpretation conflating the two requirements has been accepted by every circuit that has considered the issue.").

260 See, e.g., N-A-M v. Holder, 587 F.3d 1052, 1061 (10th Cir. 2009) (Henry, J., 
As a practical matter, dropping dangerousness from the analysis means that individuals who pose no present or future danger to society can be deported to countries where they risk being seriously harmed or killed. For example, in $R-$ $A-M$, where the BIA reversed the immigration judge's determination that possession of child pornography is not a particularly serious crime, the BIA agreed "with the Immigration Judge that there is no indication that the respondent had ever been violent in the past"; though the BLA did not dispute "the Immigration Judge's belief that the respondent would not be violent in the future," the BIA found that such a belief was "not dispositive of whether his conviction [was] for a particularly serious crime."261 However, the BIA dismissed these considerations because "it is not necessary to make a separate determination whether the alien is a danger to the community." 262 The BIA stressed that " $[t]$ he focus "is on the nature of the crime and not the likelihood of future serious misconduct." 263 Consequently, the respondent in that case was found deportable to Honduras, despite having demonstrated a greater than fifty percent chance of being persecuted there on account of his sexual orientation.

There are many other examples of situations where the failure to consider future dangerousness could result in decisions that may be viewed as unfair. Consider, for example, someone who committed a drug-related offense but is now completely sober; someone whose crime was related to a mental illness but subsequently obtained treatment and no longer poses any threat; or someone who committed a crime under extreme emotional disturbance and is unlikely to exhibit violent behavior again, such as an abused spouse who harmed her abuser. The Second Circuit's decision in Ahmetovic $v$. INS, ${ }^{264}$ where the court indicated that it was "troubled" by the BIA's failure to give separate consideration to dangerousness, involved this last scenario. ${ }^{265}$ In these situations, the past conviction may not be any indicator of present or future dangerousness. The wide range of crimes that the BLA has classified as particularly serious makes it especially problematic to infer dangerousness from the conviction itself.

\section{Failure to Apply the Principle of Proportionality}

The third way that the BIA departs from UNHCR's interpretation of Article $33(2)$ is that it does not apply the principle of proportionality. In 1985, the BIA explicitly rejected "any interpretation of the phrases 'particularly serious crime' and "serious nonpolitical crime" that "would vary with the nature of evidence of persecution." 266 The BIA reasoned that it could not find anything in the

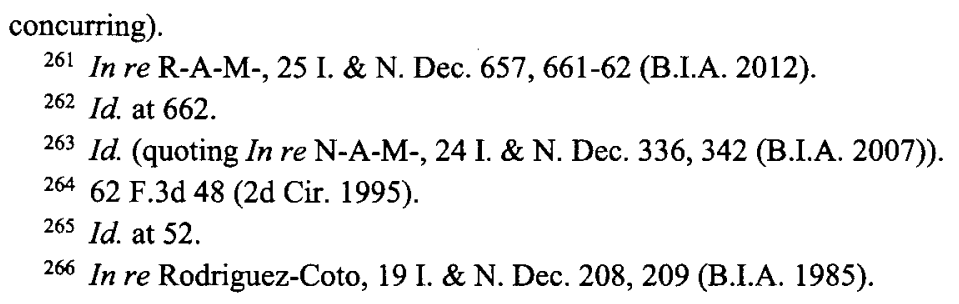


language and framework of the statute that supported this approach. ${ }^{267}$ It also noted that application of the exception presupposes that the individual has already made a showing that his or her life or freedom would be threatened on account of race, religion, nationality, membership in a particular social group, or political opinion, thereby implicitly rejecting the notion that one can-or should - differentiate between different levels of persecution. ${ }^{268}$

The Supreme Court affirmed the BIA's interpretation in INS v. AguirreAguirre, ${ }^{269}$ a case involving the serious nonpolitical crime bar. ${ }^{270}$ There, the Court reversed a Ninth Circuit decision that had relied on the UNHCR Handbook in holding that the principle of proportionality should be applied. ${ }^{271}$ While the Court acknowledged that "the U.N. Handbook provides some guidance in construing the provisions added to the INA by the Refugee Act," it stressed that the Handbook is not binding on the BIA or federal courts. ${ }^{272}$ The Court found that the Ninth Circuit should have given Chevron deference to the BIA's interpretation of an ambiguous statutory term, noting that the text and structure of the statutory section addressing a "serious nonpolitical crime" were consistent with the BIA's conclusion. ${ }^{273}$ The Court explained that "[a]s a matter of plain language, it is not obvious that an already-completed crime is somehow rendered less serious by considering the further circumstances that the alien may be subject to persecution if returned to his home country."274 The Court found it reasonable for the BIA to decide that the risk of persecution can be considered on its own as a prerequisite for withholding of removal and need not also be considered as a factor in determining whether the offense is a serious nonpolitical crime. ${ }^{275}$

Despite finding it reasonable to reject the principle of proportionality in this context, the Supreme Court routinely applies this principle in its Eighth Amendment jurisprudence. At first glance, these may seem like two unrelated areas of law, but, as immigration scholars have observed, the underlying concerns are quite similar. ${ }^{276}$ In the criminal context, the proportionality

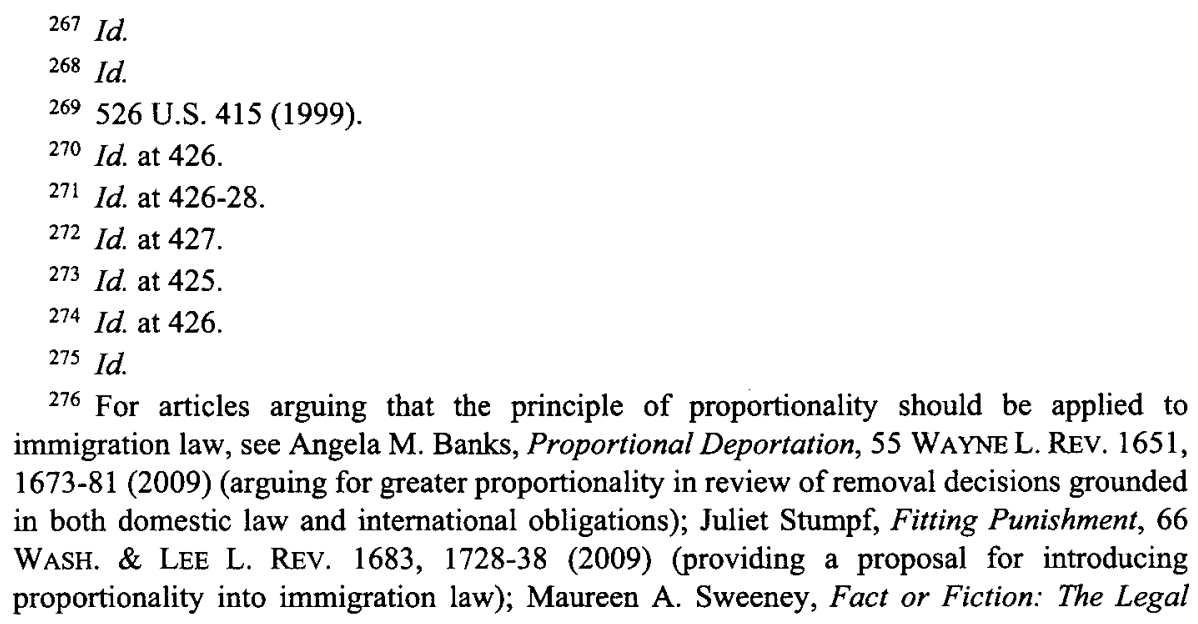

${ }^{276}$ For articles arguing that the principle of proportionality should be applied to immigration law, see Angela M. Banks, Proportional Deportation, 55 WAYNE L. REv. 1651, 1673-81 (2009) (arguing for greater proportionality in review of removal decisions grounded in both domestic law and international obligations); Juliet Stumpf, Fitting Punishment, 66 WASH. \& LEE L. REV. 1683, 1728-38 (2009) (providing a proposal for introducing proportionality into immigration law); Maureen A. Sweeney, Fact or Fiction: The Legal 
principle protects a defendant from being sentenced to a disproportionately long period of incarceration or receiving the death penalty; in the refugee context, the proportionality principle would help protect someone from receiving the disproportionate penalty of being deported to a country where there is a serious risk of persecution or death. This parallel becomes even more powerful when one takes into account that the United States has construed some of its international obligations to be consistent with its obligations under the Eighth Amendment. Specifically, when ratifying the Convention Against Torture ("CAT"), which prohibits deporting noncitizens to countries where there is a likelihood of torture, the United States entered a reservation interpreting the phrase "cruel, inhuman or degrading treatment or punishment" to mean "the cruel, unusual and inhumane treatment or punishment prohibited by the Fifth, Eighth, and/or Fourteenth Amendments to the Constitution of the United States." 277

Furthermore, the Supreme Court has recognized the deep roots of the principle of proportionality, noting that it was expressed in Magna Carta, applied for centuries by English courts, and embodied in the English Bill of Rights using the same language that was later adopted in the Eighth Amendment. ${ }^{278}$ The Court's own precedents have explicitly recognized the principle of proportionality for over a century. ${ }^{279}$ Not only has the Court applied the principle of proportionality to the death penalty, imprisonment, bail, fines, and other punishments, but it has also applied it outside the criminal context. The Court has explained that "the notion of punishment, as we commonly understand it, cuts across the division between the civil and the criminal law." 280 In the Court's view, "a civil sanction that cannot fairly be said solely to serve a remedial

Construction of Immigration Removal for Crimes, 27 YALE J. ON REG. 47, 84-86 (2010) (proposing that the Eighth Amendment standard of proportionality be applied to removal proceedings); Michael J. Wishnie, Immigration Law and the Proportionality Requirement, 2 U.C. IRVINE L. REV. 415, 435-41 (2012) (arguing that removal orders are subject to constitutional proportionality review); Michael J. Wishnie, Proportionality: The Struggle for Balance in U.S. Immigration Policy, 72 U. PITT. L. REV. 431, 457 (2011) (suggesting that Fifth and Eighth Amendment proportionality principles apply to removal orders).

277136 CONG. REC. 36,198 (1990).

278 Solem v. Helm, 463 U.S. 277, 284 (1983) ("The principle that a punishment should be proportionate to the crime is deeply rooted and frequently repeated in common-law jurisprudence.").

$279 \mathrm{Id}$. at 289 (stating that punishment by both imprisonment and death are subject to proportionality analysis); Weems v. United States, 217 U.S. 349, 362, 367 (1910) (stating "it is a precept of justice that punishment for crime should be graduated and proportioned to offense" and holding that a fifteen-year sentence to hard labor in chains was a disproportionate punishment for falsifying a public document); see also United States v. Bajakajian, 524 U.S. 321,334 (1998) ("The touchstone of the constitutional inquiry under the Excessive Fines Clause is the principle of proportionality: The amount of the forfeiture must bear some relationship to the gravity of the offense that it is designed to punish.").

${ }^{280}$ United States v. Halper, 490 U.S. 435, 447-48 (1989). 
purpose, but rather can only be explained as also serving either retributive or deterrent purposes, is punishment, as we have come to understand the term." ${ }^{281}$ For example, the Court has recognized that civil forfeiture constitutes punishment and is subject to the Eighth Amendment's excessive fines clause. ${ }^{282}$

In recent decades, the Court has clarified that the Eighth Amendment does not require strict proportionality but prohibits extreme sentences that are grossly disproportionate to the crime. ${ }^{283}$ This interpretation transfers well to the refugee context, where the idea is that the extreme penalty of being sent to a country where there is a serious risk of persecution or death is a disproportionate penalty for certain crimes. The Court has identified several factors that help compare the gravity of the offense to the harshness of the penalty. These include the harm threatened or caused to the victim, the sentence imposed, the mens rea required for the offense, and the defendant's motive in committing the crime. ${ }^{284}$ The Court has also found the personal characteristics of the offender relevant to the proportionality analysis. ${ }^{285}$ Especially in capital cases, "a defendant has wide latitude to raise as a mitigating factor 'any aspect of [his or her] character or record and any of the circumstances of the offense that the defendant proffers as a basis for a sentence less than death." "286 By contrast, the BIA has excluded offender characteristics, even if they are mitigating factors such as mental illness, from consideration in deciding whether someone should be deported to a country where he or she could be killed. ${ }^{287}$

The Supreme Court considers certain characteristics so significant that they create categorical restrictions in the implementation of the proportionality standard. For example, in Atkins v. Virginia, ${ }^{288}$ the Court held that the death penalty cannot be imposed on defendants whose intellectual functioning is in a low range. ${ }^{289}$ In Roper $v$. Simmons, the Court held that the death penalty cannot

281 Id. at 448.

282 Austin v. United States, 509 U.S. 602, 619 (1993).

${ }^{283}$ Ewing v. California, 538 U.S. 11, 30 (2003) (plurality opinion) (holding that Gary Ewing's sentence of twenty-five years to life in prison for the offense of felony grand theft under California's three strikes law was not grossly disproportionate and therefore did not violate the Eighth Amendment); Harmelin v. Michigan, 501 U.S. 957, 1001 (1991) (Kennedy, J., concurring) ("The Eighth Amendment does not require strict proportionality between crime and sentence. Rather, it forbids only extreme sentences that are 'grossly disproportionate' to the crime.").

${ }^{284}$ Solem, 463 U.S. at 292-93.

${ }^{285}$ See, e.g., Miller v. Alabama, 132 S. Ct. 2455, 2475 (2012); United States v. LaBonte, 520 U.S. 751, 764 (1997) (Breyer, J., dissenting) ("The [Sentencing] Guidelines divide sentencing factors into two basic categories: "offense" characteristics and "offender" characteristics.").

${ }^{286}$ Roper v. Simmons, 543 U.S. 551, 568 (2005) (quoting Lockett v. Ohio, 438 U.S. 586, 604 (1978) (plurality opinion)).

287 See supra note 193 and accompanying text.

288536 U.S. 304 (2002).

${ }^{289} \mathrm{Id}$. at 311 (explaining that proportionality review should be conducted under the 
be imposed on juveniles. ${ }^{290}$ In Graham v. Florida ${ }^{291}$ the Court concluded that the Eighth Amendment prohibits imposing a life sentence without possibility of parole for a juvenile convicted of a nonhomicide offense. ${ }^{292}$ Similarly, in Miller v. Alabama, 293 the Court held that "[b]y requiring that all children convicted of homicide receive lifetime incarceration without possibility of parole, regardless of their age and age-related characteristics and the nature of their crimes, the mandatory sentencing schemes before us violate [the] principle of proportionality, and so the Eighth Amendment's ban on cruel and unusual punishment." 294

Incorporating the principle of proportionately into the particularly serious crime analysis could lead to different outcomes in a subset of cases where the risk of persecution is particularly high, where deportation is likely to result in death, or where the noncitizen has certain characteristics that make him or her uniquely vulnerable to harm. For instance, incorporating this principle may require a noncitizen to demonstrate a ninety percent chance of future persecution instead of the fifty-one percent chance required for withholding of removal. This could be the case if it is known that government officials are prepared to arrest and seriously harm the individual upon arrival.

Or perhaps the risk of persecution is not exceptional, but the harm feared involves being tortured or killed, not just detained or beaten. In this situation, protection under CAT is not always available because CAT has different requirements than asylum or withholding of removal. $295 \mathrm{CAT}$ requires showing that the torture is intentional and that it would be inflicted by the government or with the government's acquiescence, for certain purposes. ${ }^{296}$ If all of these criteria are not met, then protection under CAT will be denied. Without applying the principle of proportionality, someone convicted of misdemeanor sale of marijuana, possession of child pornography, or misdemeanor indecent exposure-all of which have been characterized as particularly serious crimescould be sent to his or her death. ${ }^{297}$

evolving standards of decency).

${ }^{290}$ Roper, 543 U.S. at 578.

291560 U.S. $48(2010)$.

292 Id. at 59 ("The Court's cases addressing the proportionality of sentences fall within two general classifications. The first involves challenges to the length of term-of-years sentences given all the circumstances in a particular case. The second comprises cases in which the Court implements the proportionality standard by certain categorical restrictions on the death penalty.").

293132 S. Ct. 2455 (2012).

294 Id. at 2475.

2958 C.F.R. $\$ 208.18$ (2017).

2968 C.F.R. $\S 208.18(\mathrm{a})(1)$.

297 Singh v. Gonzales, 233 F. App'x 634, 637 (9th Cir. 2007) (noting that the BIA determined that indecent exposure was a particularly serious crime); In re R-A-M-, 25 I. \& N. Dec. 657,660 (B.I.A. 2012) (concluding that possession of child pornography is intrinsically a particularly serious offense); In re Y-L-, 23 I. \& N. Dec. 270, 274-75 (Att'y 
Finally, the noncitizen could be uniquely vulnerable to harm, perhaps because of age or due to a serious mental or physical illness. Most individuals with a mental or physical illness who apply for asylum and withholding of removal have an independent basis for fearing persecution, separate from their illness. This is because they must show that the feared persecution is on account of race, religion, nationality, political opinion, or membership in a particular social group, and courts have been reluctant to recognize mental or physical illness as the basis for membership in a particular social group. ${ }^{298}$ Even if a social group is recognized, it is often difficult to show that the harm feared is "on account of" the mental or physical illness. ${ }^{299}$ Applying the principle of proportionality in such cases would allow an immigration judge to take into consideration the additional measure of suffering an individual with a serious mental or physical illness would sustain - above and beyond showing a well-founded fear of future persecution-before issuing a deportation order based on a particularly serious crime.

The foregoing demonstrates that the BIA has parted ways with UNHCR's interpretation of the particularly serious crime bar by failing to consider all mitigating factors, dropping dangerousness from the analysis, and rejecting the principle of proportionality. This Section has also shown that UNHCR has endorsed the individual approach with the belief that this approach will promote consistency and fairness. As discussed below, however, an individualized analysis may not actually be the best way to achieve these goals.

Gen. 2002) (finding that drug trafficking is presumptively a particularly serious crime).

298 The BIA requires an immutable characteristic, social distinction, and particularity to establish a particular social group. See Temu v. Holder, 740 F.3d 887, 890, 896-97 (4th Cir. 2014) ("I conclude that the [immigration judge] and Board's determinations ... are not manifestly contrary to the law or an abuse of discretion. No adequate benchmark exists for determining whether an individual is a member of a group defined as 'bipolar individuals in Tanzania who engage in erratic behavior.' ... There is no discernible basis for readily identifying an individual as being part of the proposed group or not. ... Temu's proposed group would fail to satisfy all the required characteristics of a particular social group ...."); In re M-E-V-G-, 26 I. \& N. Dec. 227, 232-33 (B.I.A. 2014); In re W-G-R-, 26 I. \& N. Dec. 208, 209-12 (B.I.A. 2014).

${ }^{299}$ See Raffington v. INS, 340 F.3d 720, 723 (8th Cir. 2003) (rejecting "mentally ill Jamaicans" as a particular social group, finding it too large and diverse to qualify, and finding that "Raffington failed to present a prima facie case that the mentally ill or mentally ill females are being or have been persecuted in Jamaica on account of this shared characteristic"); see also Mendoza-Alvarez v. Holder, 714 F.3d 1161, 1164-65 (9th Cir. 2013) (rejecting "insulindependent diabetics who suffer from mental illnesses," finding that it lacked particularity); Khan v. Att'y Gen. of the United States, 691 F.3d 488, 496-97 (3d Cir. 2012) (holding that lack of access to mental health treatment in Pakistan did not create a well-founded fear of persecution). 


\section{POSSIBLE PATHS FoRWARD}

The previous two Parts demonstrate that the BIA's approach to the particularly serious crime bar follows neither the categorical approach used to analyze other convictions that are bars to relief under the INA, nor UNHCR's approach, which requires a robust, individualized analysis. This Part explores three possible alternatives to the BIA's current test, examining the pros and cons of each. These alternatives are: (1) applying the categorical approach; (2) applying the categorical approach to the conviction combined with an individualized assessment of dangerousness; and (3) applying a completely individualized approach. This Part concludes that the categorical approach, while imperfect, is the best way to promote consistency, fairness, and predictability.

\section{A. Applying the Categorical Approach}

The categorical approach has many benefits, which is why it has been applied to the grounds for removal and bars to relief for over a century. As Das has explained, the categorical approach provides a measure of due process in an immigration system where there is no right to appointed counsel, where many respondents are detained without access to attorneys or legal resources, and where there are no rules of evidence to constrain the Government. ${ }^{300}$ By emphasizing the statute of conviction and allowing consideration of only a limited set of documents (the record of conviction), the categorical approach helps noncitizens prepare for court without wondering what evidence the government will try to introduce against them or worrying about how the judge will subjectively weigh that evidence.

In addition, the categorical approach makes the immigration consequences of a criminal plea much more predictable. Under this approach, a noncitizen would be able to determine, before pleading guilty to an offense, whether the conviction will bar her from asylum or withholding of removal if she is placed in removal proceedings. This is an important concern not only for defendants, but also for criminal defense attorneys because the Supreme Court's decision in Padilla v. Kentucky $^{301}$ requires them to provide advice about the immigration consequences of convictions in order to be effective as counsel. ${ }^{302}$

The categorical approach has not always been easy to use due to circuit splits on important issues such as when to apply the modified categorical approach and whether judges may consult evidence outside the record of conviction to determine if an offense constitutes a CIMT. ${ }^{303}$ However, recent Supreme Court cases and the 2015 Silva-Trevino II opinion have resolved much of the confusion, clarifying how and when to apply the categorical and modified

\footnotetext{
300 Das, supra note 12 , at 1728-29.

301559 U.S. $356(2010)$.

${ }^{302}$ Id. at 374.

${ }^{303}$ Koh, supra note 68, at 297.
} 
categorical approaches. This clarification makes the outcome of the categorical analysis even more predictable than before.

The resolution of these circuit splits also means that the categorical approach will promote even greater uniformity in the immigration consequences of a conviction. This approach ensures that noncitizens convicted under the same state statute are treated identically and that defendants convicted of the same elements will face the same immigration consequences. Indeed, uniformity is one of the main reasons that courts have applied the categorical approach for so long. ${ }^{304}$ This does not mean, however, that using a categorical approach eliminates all inconsistencies. It still produces some inconsistency in the sense that two people who engaged in basically the same criminal conduct can be treated differently under the categorical approach because of variations in how state statutes are drafted.

Judicial efficiency is yet another advantage of the categorical approach, as immigration judges can make a legal determination about the effect of a conviction without taking any testimony or considering any evidence outside the record of conviction. This is an important consideration because U.S. immigration courts are extremely overloaded; each judge has thousands of cases and little time per case, leading to high levels of stress and burnout. ${ }^{305}$ This reality affects the ability of immigration judges to provide the type of robust, individualized analysis that takes into consideration all mitigating factors envisioned by UNHCR. In such a high-pressure situation, judges may not be able to hear all relevant evidence and may perceive the evidence they do hear through a distorted lens; they are more likely to rely on cognitive shortcuts and implicit biases in evaluating the facts, which can undermine rather than promote fairness. ${ }^{306}$

Lastly, a categorical approach provides an extra layer of protection to noncitizens in a system that is stacked against them. It would transform the particularly serious crime determination into a strictly legal question that would be reviewed de novo by the circuit courts, as opposed to being reviewed under the abuse of discretion standard or substantial evidence standard that some courts have decided to apply to the BIA's current test. Given the extreme consequences of the particularly serious crime determination-which can include deportation to one's death-de novo review by an appellate court could be a lifesaving measure. At the same time, however, it should be noted that de

304 See Taylor v. United States, 495 U.S. 575, 590-91 (1990); Das, supra note 12, at 1676; Koh, supra note 68, at 261 (critiquing the multiple interpretations of the categorical approach).

305 See Stuart L. Lustig et al., Inside the Judges' Chambers: Narrative Responses from the National Association of Immigration Judges Stress and Burnout Survey, 23 GEO. IMMIGR. L.J. 57, 79 (2008).

306 See Fatma E. Marouf, Implicit Bias and Immigration Courts, 45 NEW ENG. L. REV. 417, 417 (2011) (discussing the ways that immigration administrative judges are implicitly biased in their decisions due to the structure of the system). 
novo judicial review may undermine the efficiency that comes from not considering factual evidence because the circuit courts would end up investing more time reviewing particularly serious crime determinations and could potentially remand more cases to the BIA on this issue than they do now.

Applying the categorical approach to the particularly serious crime determination also has some potential drawbacks from the immigrant's perspective. Most importantly, it limits the flexibility of an adjudicator to decide that a conviction that appears serious on paper should not trigger the bar based on the individualized facts and circumstances. For example, an assault conviction may look disqualifying, but if the facts indicated that this was a mutual fight and that both parties had been convicted, a judge might view the offense in a different light. ${ }^{307}$ Similarly, a domestic violence conviction might be viewed differently if it turned out that the noncitizen convicted of domestic violence was also a victim of this offense. In this sense, the categorical approach can be overinclusive, sweeping in individuals who may not be truly dangerous.

At the same time, the categorical approach can be underinclusive, letting people remain in the country who actually do pose a danger and perhaps should be deported. Once the elements of a particularly serious crime are identified, there will always be a chance that certain crimes that appear particularly serious fail to include one or more of them. This could occur because the crime is an unusual one or because a specific state omits an element that would be expected for that type of crime.

Therefore, the challenge with applying a categorical approach to the particularly serious crime determination is coming up with the right elements. This Article proposes three elements that draw on the BIA's precedents but also incorporate UNHCR's concerns about proportionality and dangerousness. The first proposed element is the use, attempted use, or threatened use of force against a person. This element is based on the first part of the definition of a "crime of violence" under 18 U.S.C. $\S 16$, but limits it to crimes against persons. ${ }^{308}$ Crimes against property are not included in order to uphold the principle of proportionality, under the theory that exposing a person to serious

307 See Ali v. Achim, 468 F.3d 462, 464-65 (7th Cir. 2006).

308 The proposed element does not incorporate the second part of the definition of a crime of violence, which is "any other offense that is a felony and that, by its nature, involves a substantial risk that physical force against the person or property of another may be used in the course of committing the offense." 18 U.S.C. $\$ 16(b)$ (2012). The Supreme Court recently held that identical language in the Armed Career Criminal Act was unconstitutionally vague, violating due process. Johnson v. United States, 135 S. Ct. 2551, 2563 (2015). Commentators have also long criticized the second part of the crime of violence definition as subject to different interpretations. See, e.g., Timothy M. Mulvaney, Note, Categorical Approach or Categorical Chaos? A Critical Analysis of the Inconsistencies in Determining Whether Felony DWI Is a Crime of Violence for Purposes of Deportation Under 18 U.S.C. $\S 16,48$ VILL. L. REV. 697, 701-11 (2003) (discussing the various conclusions that courts have drawn about whether felony driving while intoxicated is a "crime of violence" under 18 U.S.C. $\S 16(b))$. 
physical harm by deporting them to a country where there is a high risk of persecution is a disproportionate penalty for a crime against property.

The second proposed element is the use of a dangerous weapon or force that is likely to produce serious bodily harm or death. This element further narrows the types of crimes that can be deemed particularly serious to the gravest and most dangerous offenses. It also helps uphold the principle of proportionality, allowing someone to be exposed to serious physical harm only if that person first used force likely to cause serious physical harm. Indeed, this Article argues that deporting someone to a country where there is a risk of persecution or death for an offense that does not involve a violent act is analogous to allowing capital punishment for a nonviolent offense. By 1776, nonviolent offenses had been removed from the list of capital crimes in the United States. ${ }^{309}$ By analogy, immigration judges should not be able to order someone deported to a country where his or life is threatened for a nonviolent offense.

The third proposed element is intent. The conviction need not require malicious intent, but some type of intent should be necessary. This would eliminate crimes that are based on recklessness or negligence. Intent, like the other two elements proposed above, helps satisfy the principle of proportionality, as a person should not be intentionally exposed to serious harm due to a reckless or negligent act. Intent is also critical if the conviction itself is to be the basis for assessing dangerousness. If someone negligently or recklessly injures another person, then the conviction may have resulted from an unfortunate accident that is unlikely to recur, and the person may pose no real danger to society. At the very least, the person does not pose the sort of danger that justifies being deported to a country where there is a serious risk of persecution.

Including these three elements would help ensure that only the gravest offenses will fall under the particularly serious crime bar and would help prevent the categorical approach from being overinclusive. Alternatively, the BIA could decide that a particularly serious crime must have an element indicating that the offense involved danger. This approach would be similar to the Supreme Court's interpretation of the aggravated felony bar at issue in Kawashima, where the Court held that an element could "involve" fraud or deceit without using those precise words. ${ }^{310}$ Relatively few statutes may include "danger" as an element, but they may have other elements showing that the offense clearly placed someone in danger. The risk with this approach is that the resulting classification may be overinclusive. In this situation, this Article argues that it is better to err on the side of underinclusiveness than overinclusiveness. Principles such as the rule of lenity, which requires ambiguous immigration statutes to be construed

309 Ron Fridell, Capital Punishment 13 (2004) (noting that in modern times the Supreme Court has further narrowed the list of capital crimes to a very select few).

310 Kawashima v. Holder, 132 S. Ct. 1166, 1170 (2012). 
favorably to noncitizens, also support being underinclusive rather than overinclusive when the risk associated with deportation is so high. ${ }^{311}$

In addition to requiring these elements, the particularly serious crime bar should be limited to convictions that are felonies. As both the BIA and UNHCR have recognized, a "particularly serious crime" must be more serious than a "serious crime." 12 Because the terms "misdemeanor" and "felony" reflect degrees of seriousness, it would not be logical for a misdemeanor to be deemed "particularly serious" when it represents the lower level of severity for a certain type of crime. Limiting "particularly serious crimes" to felonies also makes it clear to criminal defense attorneys that any misdemeanor plea is a "safe harbor" with respect to this bar.

Under this proposal, many offenses that the BIA has deemed particularly serious crimes would remain so, including, but not limited to, murder, firstdegree assault, and armed robbery. However, it would also narrow the range of crimes that the BIA has classified as particularly serious, eliminating crimes against property, crimes against the interests of justice, and victimless crimes. One should also keep in mind that many crimes that do not have all of the elements described above (such as drug trafficking) would still be classified as particularly serious crimes under the INA by virtue of being aggravated felonies, barring withholding of removal if the sentence is at least five years. ${ }^{313}$

\section{B. Combining a Categorical and Factual Analysis}

A second approach would be to apply the categorical approach to the conviction, as discussed above, but also require an individualized assessment of dangerousness. This method would offer some of the benefits of the categorical approach, such as greater predictability and consistency in the treatment of crimes, while also affording an individualized assessment with respect to the primary concern behind the particularly serious crime bar: danger.

This individualized assessment could help correct the overinclusive aspects of the categorical approach and be more in line with UNHCR's interpretation that dangerousness is a distinct requirement. It would prevent noncitizens who

311 Scholars have drawn parallels between the "rule of lenity" as it is known in criminal proceedings and the principle of construing laws in favor of noncitizens in immigration proceedings. See Peter L. Markowitz, Deportation is Different, 13 U. PA. J. ConsT. L. 1299, 1321-25 (2011) (discussing the application of the traditional criminal rule of lenity doctrines to deportation proceedings); Brian G. Slocum, Canons, the Plenary Power Doctrine, and Immigration Law, 34 FLA. ST. U. L. REV. 363, 372-73 (2007) (stating the rule of lenity was "[d] esigned by the Court to protect a vulnerable minority"); see also INS v. Elias-Zacarias, 502 U.S. 478, 487-88 (1992) (Stevens, J., dissenting) (quoting the Court's decisions directing courts to apply the rule of lenity in immigration proceedings); Fong Haw Tan v. Phelan, 333 U.S. 6, 10 (1948) (applying the rule of lenity to deportation proceedings by "resolv[ing] [] doubts in favor of [the] construction [that favors the alien] because deportation is a drastic measure and at times the equivalent of banishment or exile").

312 In re Frentescu, 18 I. \& N. Dec. 244, 245-46 (B.I.A. 1982).

313 See 8 U.S.C. $\S 1231$ (b)(3)(B) (2012). 
have been rehabilitated or who committed violent acts in unique circumstances or emotional states that are unlikely to recur from being deported to countries where they face a risk of serious harm. The abused spouse who committed a violent act against the abuser or the individual with mental illness who committed a crime before receiving proper treatment would have an opportunity to demonstrate that they pose no future danger to the community. If this approach were adopted, it might be possible for the elements to be relaxed (for example, not requiring force likely to result in serious bodily injury), because the elements are not being relied upon to satisfy the dangerousness requirement.

This combination of a categorical and individualized determination is not unprecedented. The case that best exemplifies this mode of analysis is the Supreme Court's 2009 decision in Nijhawan v. Holder, ${ }^{314}$ which examined the aggravated felony ground that applies if a noncitizen is convicted of "an offense that ... involves fraud or deceit in which the loss to the ... victims exceeds $\$ 10,000 . " 315$ The Court applied the categorical approach to the "fraud or deceit" requirement but held that the $\$ 10,000$ loss threshold refers to the specific circumstances in which the offender committed the crime, rather than to an element of the crime. ${ }^{316}$ The Court emphasized that the words "in which" can refer to the conduct involved in the commission of the offense, rather than the elements of the offense. ${ }^{317}$ In addition, the Court reasoned that most statutory offenses do not have a specific loss amount as an element, so the provision would be largely pointless unless the loss amount called for circumstancespecific application. ${ }^{318}$

The BIA also used this type of approach that combines a categorical and factual analysis in In re Babaisakov, ${ }^{319}$ which interpreted the same aggravated felony ground that was at issue in Nijhawan. ${ }^{320}$ There, the BIA explained that a ground for removal might require proof of a conviction tied to the statutory elements of a criminal offense as well as proof of additional facts that are not tied to those statutory elements. Like the Supreme Court, the BIA found that adjudicators are not limited to the record of conviction in determining the nonelement facts. ${ }^{321}$ Thus, adjudicators may consider restitution orders, testimony, and any other reliable evidence that bears on the loss to the victim. ${ }^{322}$ The BIA explained:

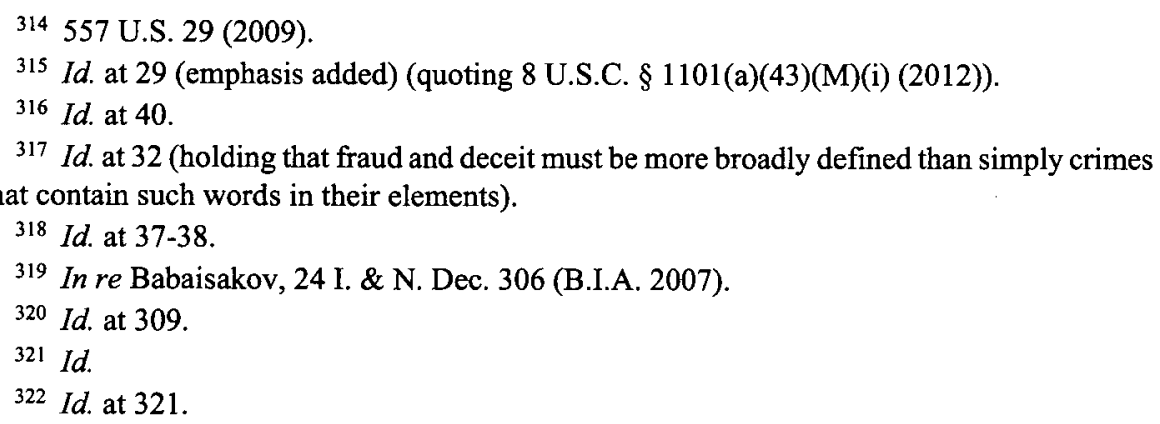


[B]ecause we are looking for a fact that was part of the crime, but not a fact that must have been proved to establish guilt, the independent assessment of that fact during a removal hearing does not encroach on the principal purpose of the criminal proceedings, which was the determination of guilt under the elements of the criminal statute. ${ }^{323}$

This approach is tricky, however, and has been heavily criticized by immigration scholars because it is difficult to discern when the INA is referring to a fact versus an element of the crime, thereby eroding the predictability and consistency that a strictly categorical approach provides. ${ }^{324}$ In another case, In re Gertsenshteyn, ${ }^{325}$ where the BIA tried to apply a combination approach, its analysis was rejected by the Second Circuit. In that case, the BIA interpreted an aggravated felony provision that applies to a noncitizen convicted of an offense relating to transportation for purposes of prostitution if "committed for commercial advantage." 326 The BIA found that "committed for commercial advantage" was not an element of the offense or a basis for sentence enhancement and, therefore, required the circumstances of the specific crime to be considered ${ }^{327}$ It noted that only three federal statutes required "commercial advantage" as an element. ${ }^{328}$ Furthermore, the BIA distinguished the "commercial advantage" language from length of sentence restrictions by pointing out that "only the latter can readily be ascertained by consulting conviction records." " 229 The BIA concluded that parties must be able to offer evidence outside of the record of conviction to keep the "commercial advantage" language from being a nullity. ${ }^{330}$ While the BIA recognized that allowing the immigration judge to examine the underlying nature of the offense might cause "some burden to the system," it nevertheless gave effect to the language used by Congress. ${ }^{331}$

The Second Circuit rejected the BIA's reasoning in Gertsenshteyn, stressing that the use of the categorical approach follows from Congress's use of the word "convicted." 332 The court found that it was improper for the BIA to abandon the traditional categorical approach for "practical" reasons, such as the small

$323 I d$.

324 See, e.g., Das, supra note 12, at 1694; Koh, supra note 68, at 260; Rebecca Sharpless, Towards a True Elements Test: Taylor and the Categorical Analysis of Crimes in Immigration Law, 62 U. MIAMI L. REV. 979 passim (2008) (arguing against allowing immigration adjudicators to make findings of fact about the manner in which a crime was committed).

32524 I. \& N. Dec. 111 (B.I.A. 2007), rev'd sub nom. Gertsenshteyn v. U.S. Dep't of Justice, 544 F.3d 137 (2d Cir. 2008).

326 Id. at 111.

327 Id. at 113-14.

$328 \mathrm{Id}$.

$329 \mathrm{Id}$. at 115.

${ }^{330} \mathrm{Id}$. at $115-16$.

331 Id. at 116.

332 Gertsenshteyn v. U.S. Dep't of Justice, 544 F.3d 137, 145 (2d Cir. 2008). 
number of statutes that include "commercial advantage" as an element of the crime. ${ }^{333}$ Not only did the court dispute that only a few statutes implicate this aggravated felony ground, but, more importantly, it stressed that the Government finding it difficult to prove that a conviction falls within the statutory definition of aggravated felony "is no reason for immigration courts to renounce the restrictions that the courts have said the law requires." 334

Because the combination approach has only been accepted in Nijhawan and Babaisakov, which interpret the same aggravated felony ground, it may be a risky way to approach the particularly serious crime bar. The argument would be that the phrase "having been convicted of a particularly serious crime" is a subordinate clause, and "the alien ... constitutes a danger to the community" is an independent clause that requires a separate fact-specific inquiry. ${ }^{335}$ The statutory language in cases involving the particularly serious crime bar is not as clear as the sentence that was parsed in Nijhawan and Babaisakov, which used the words "in which."

Separate from the questions of statutory interpretation that this combination approach raises, there are also practical concerns about making individualized fact-specific findings about future dangerousness. To begin with, although predictions about long-term dangerousness are extremely common in the legal system, studies have shown that they are not very accurate or reliable. ${ }^{336}$ In the

333 Id.

334 Id. at 148 .

3358 U.S.C. $\S \S 1231$ (b)(3)(A)(ii), (iv) (2012).

336 See Erica Beecher-Monas \& Edgar Garcia-Rill, Danger at the Edge of Chaos: Predicting Violent Behavior in a Post-Daubert World, 24 CARDOzo L. REV. 1845, 1846-48, $1849-50,1868-79$ (2003) (discussing the weaknesses of psychiatric predictions about future dangerousness and exploring the usefulness of alternative methods); Erica Beecher-Monas, The Epistemology of Prediction: Future Dangerousness Testimony and Intellectual Due Process, 60 WASH. \& LEE L. REV. 353, 372-78 (2003) (discussing what is wrong with clinical predictions of dangerousness and why admitting them into capital sentencing proceedings violates basic premises of the rule of law); M. Neil Browne \& Ronda R. Harrison-Spoerl, Putting Expert Testimony in Its Epistemological Place: What Predictions of Dangerousness in Court Can Teach Us, 91 MARQ. L. REv. 1119, 1123 (2008) (challenging the assumption that predictions of violence are "sufficiently objective, neutral, or 'true' to warrant anything but a wary acceptance in the judicial system"); Bernard L. Diamond, The Psychiatric Prediction of Dangerousness, 123 U. PA. L. REV. 439 (1974) (discussing psychiatrists' difficulties in predicting dangerousness); Randy K. Otto, On the Ability of Mental Health Professionals to "Predict Dangerousness": A Commentary on Interpretations of the "Dangerousness" Literature, 18 LAW \& Psychol. REV. 43, 67-68 (1994) ("Despite 25 years of research, social scientists have barely scratched the surface of risk assessment as a predictive tool."); Eugenia T. La Fontaine, Note, A Dangerous Preoccupation with Future Danger: Why Expert Predictions of Future Dangerousness in Capital Cases are Unconstitutional, 44 B.C. L. REV. 207, 233-36 (2002) (discussing the reliability and accuracy of psychiatric expert testimony of future dangerousness and arguing that heightened standards of reliability and accuracy should be used when determining the admissibility of evidence at the sentencing phases of capital trials). 
criminal justice system, dangerousness predictions are made in bail, pretrial detention, sentencing, prison administration, parole, and early release decisions. Similarly, in the immigration system, dangerousness predictions are made in detention and bond decisions, as well as for various waivers, forms of relief, and certain bars to relief. For example, there is the bar to withholding of removal that applies if "there are reasonable grounds to believe that the alien is a danger to the security of the United States." 337 The Supreme Court has stated that "from a legal point of view there is nothing inherently unattainable about a prediction of future criminal conduct," recognizing that "[s]uch a judgment forms an important element in many decisions." 338

Although the legal system often depends on the expertise of psychiatrists in assessing future dangerousness, psychiatrists themselves have questioned the reliability of such predictions. In 1983, the American Psychiatric Association published a Statement on Prediction of Dangerousness, which acknowledged that "[s]tudies have shown that even with patients in which there is a history of violent acts, predictions of future violence will be wrong for two out of every three patients." ${ }^{\prime 3} 39$ Psychiatric assessments of future dangerousness are normally based on the identification of various factors associated with potential dangerous behavior, including "the context, opportunity, frequency, intensity, and severity of past dangerous behavior; identification of circumstances and stimuli that trigger dangerous behavior such as substance abuse or intoxication, paranoid psychosis, work conflicts, economic problems, interpersonal relationship difficulties, or loss of loved one (real or imagined), and recidivism." 340 However, even today, disagreements exist about whether it is best to rely on general risk factors; a clinician's individualized assessment of dangerousness; or a structural clinical assessment that uses a checklist of sorts, to ensure that the clinician takes into consideration various factors and gives them proper weight. ${ }^{341}$ Newer

3378 U.S.C. $\S 1231($ b)(3)(B)(iv).

${ }^{338}$ Schall v. Martin, 467 U.S. 253, 278 (1984); see also Barefoot v. Estelle, 463 U.S. 880, 902-03 (1983) (holding that the use of psychiatrists in death penalty cases to prove premeditation was legally permissible); Jurek v. Texas, 428 U.S. 262, 275 (1976) (plurality opinion) ("[A]ny sentencing authority must predict a convicted person's probable future conduct when it engages in the process of determining what punishment to impose."); Baxstrom v. Herold, 383 U.S. 107, 114 n.5 (1966) (noting that diagnosis of criminal insanity can be used to predict future propensity to commit crime).

339 AM. PsyChIATRIC Ass'N, FACT SHEET: VIOLENCE AND MENTAL ILLNESS (1998) (quoting Am. Psychiatric Ass'N, Statement on Prediction of Dangerousness (1983)).

340 Robert T. M. Phillips, Predicting the Risk of Future Dangerousness, 14 AM. MED. Ass'N J. ETHICS 472, 474 (2012) (noting that a clinician's predictive ability for future criminality is a controversial subject for scholars).

${ }^{341}$ Id.; see also A. Bauer et al., Reflections on Dangerousness and Its Prediction-A Truly Tantalizing Task?, 21 MED. \& L. 495, 506-16 (2002) (reviewing existing theory and knowledge on risk assessment and prediction and explaining the shortcomings of different approaches) 
techniques that draw on developments in genetics and neuroscience are also plagued with problems. ${ }^{342}$

In immigration court, where at least forty percent of noncitizens are unrepresented, relatively few will be able to afford a psychiatric expert to prepare an evaluation or testify about future dangerousness for purposes of the particularly serious crime bar. ${ }^{343}$ Nor is the Government likely to pay for an expert of its own. Therefore, in most cases, immigration judges would be making dangerousness assessments on their own. As noted above, they already do this for bond determinations and certain other types of decisions, but less is usually at stake in those decisions than deportation to a country where a serious risk of future persecution has been established. Allowing judges to rely on their own highly subjective assessment of dangerousness without the benefit of any psychiatric expertise may also result in discrimination against certain groups that are stereotyped as dangerous, such as individuals with mental illness. ${ }^{344}$

Because an adjudicator's assessment of dangerousness is highly subjective, it is also unpredictable. Adding this component of unpredictability, therefore, undercuts one of the major benefits of applying the categorical approach.

342 Erica Beecher-Monas \& Edgar Garcia-Rill, Genetic Predictions of Future Dangerousness: Is There a Blueprint for Violence?, 69 LAW \& CONTEMP. PROBS. 301, 33239 (2006) (examining the problems of predicting violence based on genetic information); Adam Lamparello, Using Cognitive Neuroscience to Predict Future Dangerousness, 42 Colum. Hum. RTS. L. Rev. 481, $533-39$ (2011) (discussing and responding to potential objections about the use of cognitive neuroscience in assisting with dangerousness determinations).

343 See Ingrid V. Eagly \& Steven Shafer, A National Study of Access to Counsel in Immigration Court, 164 U. PA. L. REV. 1, 8-9 (2015).

344 Research has yielded inconsistent and conflicting results about whether there is a significant association between mental illness and violence. See Michael A. Norko \& Madelon V. Baranoski, The Prediction of Violence; Detection of Dangerousness, 8 BRIEF TREATMENT \& CRISIS INTERVENTION 73, 76 (2008) (offering data showing that the combination of drug use with mental illness as increasing the likelihood of violence, but that mental illness alone is less clear as a predictor). Even if such an association exists, however, it is uncontested that most individuals with mental illness are not violent and most violent individuals do not have mental illness; in fact, studies have shown that socio-demographic factors contribute significantly more to violence than mental health factors. See AM. PSYCHIATRIC Ass'N, supra note 339, at 1-3; Edward P. Mulvey, Assessing the Evidence of a Link Between Mental Illness and Violence, 45 HosP. \& COMMUNITY PSYCHIATRY 663, 665 (1994) (finding that socioeconomic factors or history of violence are much more predictive of violent behavior); see also John W. Parry, The Death Penalty and Persons with Mental Disabilities: A Lethal Dose of Stigma, Sanism, Fear of Violence, and Faulty Predictions of Dangerousness, 29 MENTAL \& PHYSICAL DiSABILITY L. REP. 667, 667 (2005) (arguing that the finding of dangerousness "is a disgraceful sham, particularly when applied to persons who already are stigmatized, feared by society, and often viewed by judges and jurors as being dangerous before sentencing even begins"). See generally JOHN WESTON PARRY, MENTAL DisABILITY, VIOLENCE, AND FutURE DANGEROUSNESS: MYTHS BEHIND THE PRESUMPTION OF GUILT (2013). 
Defendants will no longer have peace of mind knowing that, by agreeing to a certain plea agreement, they are not forfeiting their eligibility for asylum or withholding of removal. They will also have to worry about whether or not the immigration judge will perceive them as dangerous. And they will be left wondering what evidence the Government might produce to try to portray them as dangerous.

Another practical concern with adopting an approach that requires an individualized assessment of dangerousness is efficiency. As one federal judge noted, "[a] separate determination of an alien's potential dangerousness would require a prediction as to an alien's potential for recidivism and would lead to extensive, drawn-out hearings complete with psychological evaluations and expert testimony." ${ }^{445}$ On the other hand, former BIA Member Rosenberg has argued that "[dangerousness] determinations are routinely made in other contexts, such as bond determinations, with little or no evidentiary display or legal argument and, consequently, with little or no delay." 346 While Rosenberg's statement may be correct, one has to wonder whether dangerousness assessments made in this way are even less accurate and reliable than those based on actual evidence and expert testimony.

These practical concerns, combined with the complicated legal question about whether the statutory language of the particularly serious crime bar can be interpreted as requiring a categorical analysis of the conviction plus a factspecific analysis of dangerousness, suggest that this may not be the best way forward. In fact, of the three approaches discussed in this section, this one most closely resembles the BLA's current approach, combining an examination of the elements with a factual inquiry, and ultimately producing results that seem more arbitrary, unpredictable, and unfair than either a strictly categorical or entirely individualized analysis.

\section{Applying an Individualized Approach}

A third approach would be a completely individualized assessment of whether a given offense should be classified as a particularly serious crime. This assessment should be robust in the sense that no mitigating or aggravating factors should be excluded from consideration. Offender characteristics, including mental illness, as well as evidence of rehabilitation and dangerousness should be taken into consideration, as these are all relevant and potentially mitigating factors. By giving immigration judges more flexibility and the ability to fine-tune their decisions to the specific circumstances of each case, an individualized analysis could potentially avoid the concerns about over and underinclusiveness that arise under the categorical approach. An individualized

${ }^{345}$ Zardui-Quintana v. Richard, 768 F.2d 1213, 1222-23 (11th Cir. 1985) (Vance, J., concurring in the judgment).

${ }^{346}$ In re Q-T-M-T-, 21 I. \& N. Dec. 639, 670 (B.I.A. 1996) (Rosenberg, Bd. Member, concurring in part and dissenting in part) (disagreeing with the majority's contention that such a determination of dangerousness was an onerous requirement). 
analysis would also be consistent with UNHCR's interpretation of Article 33(2) of the Refugee Convention. ${ }^{347}$

At the same time, however, an individualized approach could actually exacerbate UNHCR's underlying concerns about consistency and fairness. Because every case has unique facts, noncitizens who committed very similar crimes could end up being treated very differently. Even in cases where the facts are similar, the outcomes may be different because of the highly subjective nature of such individualized decisions. Different judges will perceive the seriousness of crimes differently, give different weight to various factors, and make different assessments of credibility when testimony is provided about the facts and circumstances surrounding the offense. This will lead to highly subjective decisions about whether or not a crime is "particularly serious." Allowing the determination to be so subjective can lead to arbitrary, inconsistent, and unfair decisions. An individualized approach will also make the particularly serious crime determination highly unpredictable, giving defendants and their attorneys no guidance about how a given plea will affect their eligibility for asylum and withholding of removal.

Furthermore, in the huge number of cases where the respondent is unrepresented, detained, or both, mitigating factors may never be introduced into evidence. This could be because the respondent is unaware of the relevance of such factors without advice from counsel, or because the respondent lacks the resources or ability to obtain and submit relevant documentary evidence. Detained respondents, in particular, face significant challenges in obtaining documents, declarations, and witnesses to testify on their behalf, especially if they are located in remote parts of the country, far from their friends and families. Because the burden of proof is on the respondent to prove eligibility for asylum and withholding of removal, he or she is responsible for providing the factual evidence to show that the particularly serious crime bar does not apply.

It is often far easier for the Government to present factual evidence than for the respondent. As Judge Berzon on the Ninth Circuit has noted, additional factfinding "effectively serves as a one-way ratchet that always favors the Government." 348 For example, the Government often has easy access to arrest reports, witness statements, and other documents that could paint a far worse picture of the crime than the statute of conviction alone. Because the officers and witnesses involved are unlikely to come to immigration court to testify, in most cases there would be no opportunity for the respondent to cross-examine any of these individuals, making it difficult to challenge the evidence submitted by the Government. Because the Government tends to be in a better position to introduce factual evidence, the individualized analysis may, as a practical

347 See supra Section II.B.

348 United States v. Aguila-Montes de Oca, 655 F.3d 915, 962 n.18 (9th Cir. 2011) (Berzon, J., concurring), abrogated by Descamps v. United States, 133 S. Ct. 2276 (2013). 
matter, give the immigration judge more flexibility in deciding that a crime is particularly serious than in concluding the opposite.

Another drawback to an individualized approach is that adjudicators seem uncertain about when an inquiry into the underlying facts and circumstances of a crime, especially mitigating factors, turns into a re-adjudication of guilt or innocence, thereby "going behind" the conviction. The BIA's decision in $G-G-S$ - is an excellent example of this issue. ${ }^{349}$ Because it is possible for the criminal court to take mental illness into consideration in adjudicating guilt and in sentencing, the BIA held that immigration judges are constrained by how the criminal court handled this issue. ${ }^{350}$ If mental illness was not raised as an issue in criminal court, then, under $G-G-S$-, it is improper for the immigration judge to consider it as part of the particularly serious crime determination. The flaw in this reasoning is that the vast majority of criminal charges are resolved through plea agreements where mitigating factors are raised behind the scenes in negotiations with the prosecutor or not raised at all in order accept a quick plea offer and remove the risk of further detention or a more severe sentence. ${ }^{351}$ Thus, the only opportunity to bring these mitigating factors to a judge's attention may be after the conviction, when the individual is fighting the particularly serious crime bar in immigration court. But, even if a completely individualized test were allowed, immigration judges may be reluctant to give weight to factors that they believe-rightly or wrongly - were already taken into consideration by the criminal court.

Finally, adopting an individualized approach would not provide the efficiency of the categorical approach. Judges would have to take the time to examine documentary evidence, listen to testimony, and try to make sure that they take all relevant facts into consideration. In cases where the assessment was highly efficient because little evidence was provided, the individualized approach likely would not be protecting the interests of the respondent. Thus, the key benefits of the categorical approach-consistency, predictability, and efficiency-would all be lost with an individualized analysis, while also potentially sacrificing fairness due to an imbalance of knowledge, power, and resources between the parties.

\section{RECOMMENDATIONS}

All three of the approaches discussed above-categorical, a combination of categorical and factual analysis, and completely individualized - raise concerns about fairness, consistency, and notice. In the context of immigration adjudication in the United States, however, the categorical approach comes closest to satisfying these principles. The absence of counsel; high rate of

${ }^{349}$ In re G-G-S-, 26 I. \& N. Dec. 339, 347 (B.I.A. 2014).

${ }^{350} \mathrm{Id}$.

351 See Fatma Marouf, Assumed Sane, 101 CORNELl L. REv. ONLINE 25, 30 (2016) (discussing the incentive that defendants have to plead guilty even when it has adverse immigration consequences). 
detention; speed with which detainees are moved through the court process; and concerns about institutional competence, all make it difficult to produce the type of evidence needed to support individualized assessments. Most people facing deportation in the United States simply cannot afford the high cost of litigating an individualized issue that often requires expert testimony, psychological evaluations, and voluminous documentation in order to prevail. The categorical approach relieves noncitizens of this evidentiary burden. It also relieves courts of litigation that tends to have a low return. At the end of the day, the meaning of the documents submitted "will often be uncertain," and the facts they contain "may be downright wrong." 352

However, it would be a mistake to view the categorical approach as "neutral." One of the common critiques of the categorical approach is that it can provide an undeserved windfall for immigrants by narrowing the judicial inquiry and keeping out bad facts. ${ }^{353}$ But, as discussed above, this approach can also benefit the Government by keeping out facts that favor the immigrant. ${ }^{354}$ Confusion among judges about how to apply the categorical approach also tends to cut against unrepresented immigrants who are ill-equipped to make legal arguments disputing the Government's interpretation. ${ }^{355}$

One way to try to mitigate the limitations of the categorical approach is to adopt a burden-shifting framework for the particularly serious crime bar. This type of burden-shifting approach is already applied in many other areas of immigration law, such as establishing removability; ${ }^{356}$ showing a well-founded

${ }^{352}$ Descamps, 133 S. Ct. at 2289.

${ }^{353}$ See Evan Tsen Lee, Mathis v. U.S. and the Future of the Categorical Approach, 101 MINN. L. REV. HEADNOTES 263, 269 (2016) (explaining the ideological argument against the categorical approach as a "windfall" for immigrants that allows the immigrant to "escape his just deserts merely because some hypothetical defendant could be convicted under that statute for conduct that would not fit the standard").

${ }^{354}$ See Martinez v. U.S. Att'y Gen., 413 F. App'x 163, 167-68 (11th Cir. 2011) (finding an alien's conviction for child neglect to categorically constitute "crime of child abuse" in a "heartbreaking case" and calling the result "profoundly unfair, inequitable, and harsh")

${ }^{355}$ See Lee, supra note 353 , at 265-68 (stating that lower federal court judges are "completely confused" by the categorical approach).

${ }^{356}$ Under the INA, the Government must first establish removability by clear and convincing evidence. 8 U.S.C. $\S 1229$ a(c)(3)(A) (2012). The burden then shifts to the noncitizen to establish relief from removal by a preponderance of the evidence. 8 C.F.R. $\S 1240.8(\mathrm{~d})$ (2017); see also 8 U.S.C. § 1229a(c)(4)(A). 
fear of future persecution; $; 57$ determining whether the firm resettlement bar to asylum applies; $; 58$ and even proving U.S. citizenship. 359

There are different ways to apply this burden-shifting approach. For example, the Government could bear the initial burden of establishing a rebuttable presumption that the categorical approach triggers the particularly serious crime bar. Then, the noncitizen could have an opportunity to rebut that presumption by a preponderance of evidence that the crime was not particularly serious based on individualized facts. This approach would provide a way to push back against an application of the categorical approach that produces unfair results for the immigrant. Although it would not provide the same level of predictability as a purely categorical approach, the use of a presumption would provide greater predictability than the BIA's current haphazard approach.

Some might argue, however, that this application of a burden-shifting framework does not help prevent windfalls for immigrants. In order to address that concern, courts could alternatively allow either party to rebut the presumption established by the categorical approach. Allowing either party to rebut a presumption is not uncommon. For example, a criminal sentence that falls within the range permitted by the Federal Sentencing Guidelines is presumed reasonable, but either party can rebut that presumption by demonstrating that the sentence is unreasonable in light of other factors listed in the statute ${ }^{360}$ Similarly, here, the result of a categorical analysis could be presumed to provide a reasonable determination regarding whether a crime is "particularly serious," but either party could be allowed to rebut that presumption by introducing individualized facts showing that the result of the categorical approach is unreasonable.

Currently, one of the greatest concerns about the categorical approach is that the most recent cases at the time of this writing suggest its future is uncertain. In

357 "An applicant who has been found to have established such past persecution shall also be presumed to have a well-founded fear of persecution on the basis of the original claim. That presumption may be rebutted if an asylum officer or immigration judge makes one of the findings described in paragraph (b)(1)(i) of this section." 8 C.F.R. $\S 1208.13$ (b).

358 See Maharaj v. Gonzales, 450 F.3d 961, 972, 976-77 (9th Cir. 2006) (en banc) (explaining that the Government bears the initial burden of showing an offer of permanent resident status, citizenship, or some other type of permanent resettlement in a third country; once the Government provides evidence of such an offer, the burden shifts to the applicant to show that the nature of his stay and ties was too tenuous, or the conditions of his residence too restricted, for him to be firmly resettled).

359 See Scales v. INS, 232 F.3d 1159, 1163 (9th Cir. 2000) (explaining that "[e]vidence of foreign birth ... gives rise to a rebuttable presumption of alienage," shifting the burden of proving citizenship by a preponderance of the evidence to the individual).

360 See United States v. Kristl, 437 F.3d 1050, 1054 (10th Cir. 2006) ("[A] sentence that is properly calculated under the Guidelines is entitled to a rebuttable presumption of reasonableness. This is a deferential standard that either the defendant or the government may rebut by demonstrating that the sentence is unreasonable when viewed against the other factors delineated in $\$ 3553(\mathrm{a})$. ."). 
Mathis v. United States, ${ }^{361}$ decided in 2016, the Supreme Court upheld the strict application of the categorical approach in determining which prior convictions count toward enhanced sentences for federal crimes. ${ }^{362}$ But the Court was surprisingly split five to three in that case. Justice Breyer and Justice Ginsburgwho were part of the eight-to-one majority in Descamps-dissented in Mathis, critiquing the majority's approach as "not practical" and noting that "there are very few States where one can find authoritative judicial opinions that decide the means/elements question." 363 This characterization of the categorical approach contradicts the reasoning in Descamps and other decisions finding that the categorical approach helps avoid the "practical difficulties and potential unfairness of a factual approach." 364

While Justice Kennedy concurred with the majority in Mathis, his opinion also criticized the categorical approach for producing "arbitrary and inequitable results," at least with respect to the sentencing scheme at issue in that case. ${ }^{365}$ These concerns appear to be related to situations where the categorical approach results in "windfalls" for the noncitizen. Justice Kennedy not only urged Congress to take action, but also concluded that the Court should "revisit its precedents in an appropriate case," opening the door to overruling cases such as Descamps. ${ }^{366}$ If Justice Kennedy swings to the other side, the categorical approach could be in jeopardy. ${ }^{367}$

Given the ambivalence of at least three Justices on the Court about how the categorical approach works in practice, it is important to identify areas of law where the categorical approach would help, rather than hinder, predictable and consistent decision-making. The BIA's decisions on the particularly serious crime bar provide a compelling example of one such area. Before scrapping the categorical approach, courts should take a long, hard look at the arbitrary and inequitable outcomes that are reached in this exceptional situation where the categorical approach is not applied.

361136 S. Ct. 2243 (2016).

${ }^{362} \mathrm{Id}$. at 2248 (declining to find an exception to the categorical approach under the Armed Career Criminal Act).

${ }^{363}$ Id. at 2263-64 (Breyer, J., dissenting).

364 Taylor v. United States, 495 U.S. 575, 601 (1990); see also Descamps v. United States, 133 S. Ct. 2276, 2289 (2013).

${ }^{365}$ Mathis, 136 S. Ct. at 2258 (Kennedy, J., concurring).

${ }^{366} \mathrm{Id}$.

${ }^{367}$ Another recent decision holding that the absence of a jurisdictional element is immaterial in applying the categorical approach resulted in an unconventional five to three split among the Justices, with Chief Justice Roberts and Justices Kennedy, Ginsburg, Alito, and Kagan in the majority and Justices Thomas, Breyer, and Sotomayor dissenting. See Torres v. Lynch, 136 S. Ct. 1619 (2016). 


\section{CONCLUSION}

The particularly serious crime bar is the only bar to relief from removal that is based on a conviction but not analyzed using the categorical approach. The BIA's current approach combines the worst aspects of both categorical and factual analysis, placing individuals facing deportation in enormous danger based on arbitrary determinations about the seriousness of their crimes.

Applying the categorical approach to this bar would promote consistency, predictability, efficiency, and fairness in a decision that can have the draconian consequence of sending someone to a country where there is a serious risk of persecution.

While UNHCR has interpreted the particularly serious crime bar as requiring an individualized analysis, its underlying concerns about consistency and fairness are actually better served using the categorical approach, as long as the elements of a particularly serious crime are carefully and narrowly defined to ensure that the principle of proportionality is not violated and that the conviction itself signals dangerousness. Finally, applying the categorical approach would provide a consistent mode of analysis for all particularly serious crime determinations because the convictions that Congress has defined as per se particularly serious crimes (aggravated felonies) are already analyzed using this approach. Although the categorical approach is far from perfect, it is preferable to the highly subjective nature of either a purely individualized analysis or one that combines an examination of elements and facts. For a noncitizen facing deportation to persecution or possible death, only an approach with objective, predictable consequences offers any peace of mind. 